\title{
A New Node of Science in Action: The 1761 Transit of Venus and Hell's Transition to Fame
}

I reckon there is no one interested in astronomy who does not wait impatiently to learn what was observed during the recent meeting of Venus with the Sun, especially since there is no other encounter between celestial bodies from which we are able to ascertain with a greater degree of exactness the still unknown, or not yet sufficiently well defined, parallaxes of the Sun and Venus.

EUSTACHIO ZANOTTI $1761^{1}$

\section{A Golden Opportunity}

The above assessment of Hell's Bolognese colleague Eustachio Zanotti could hardly have been more to the point. The passage (or transit) of Venus in front of the Sun as seen from the Earth is a rare astronomical phenomenon: it comes in pairs separated by eight years, after which it does not take place for more than a whole century. The first transit of Venus observed by means of astronomical equipment was in 1639 . Since then, transits of Venus have occurred in the years 1761 and 1769,1874 and 1882, and 2004 and 2012-but they will not happen again until 2117 and 2125. The 1639 transit of Venus made no immediate impact and (as far is known) was only observed by two amateur astronomers in the English countryside. ${ }^{2}$ By contrast, the pre-calculated transits of 1761 and

1 Eustachio Zanotti, De Veneris ac Solis Congressu Observatio habita in Astronomico Specula Bononiensis Scientiarum Instituti Die 5Junii MDCCLXI (Bologna: Laelii e Vulpe, 1761), 1.

2 The observers were Jeremiah Horrocks (c.1618-41), observing from outside Liverpool, and his friend Simon Crabtree (1610-40), observing from the Manchester area. See Peter Aughton, The Transit of Venus: The Brief, Brilliant Life of Jeremiah Horrocks, Father of British Astronomy (London: Windrush, 2004); Allan Chapman, "Jeremiah Horrocks, William Crabtree, and the Lancashire Observations of the transit of Venus of 1639," in Proceedings of the International Astronomical Union, Volume 2004, June 2004: Transits of Venus; New Views on the Solar System and Galaxy, Proceedings IAU Colloquium, ed. Don W. Kurtz, no. 196 (Cambridge: Cambridge University Press, 2004), 3-26; Thomas Posch and Franz Kerschbaum, "Kepler, Horrocks, Hevelius und der Venustransit von 1631," in Astronomy in and around Prague. Colloquium of the Working Group of the History of Astronomy, Prague, September 20, 2004, ed. Gudrun Wolfschmidt and Martin Šolc (Prague: Univerzita Karlova, 2005), 89-100. 
1769 attracted massive public interest, as well as lavish funding from European governments for expeditions into remote regions of the world. The principal scientific reason was that the transits of Venus were seen as unique opportunities to calculate the distance between the Earth and the Sun, a coveted feat in the "quantifying spirit" of the Enlightenment. Early on in the seventeenth century, Kepler's groundbreaking work on the orbits of the planets had laid the foundations for calculations that enabled sky-watchers to be prepared for spectacular events, such as transits of Venus. The Newtonian theory of gravitation and mechanics further improved the methods for calculating the movements of the planets, but there were still considerable uncertainties about the actual distances between the Sun and the various planets. A transit of Venus was seen as the best way to solve the problem. As pointed out by Edmond Halley (1656-1742), who forecasted the 1761 and 1769 transits, ${ }^{3}$ observations of Venus in front of the Sun from widely separated sites on the Earth would reveal tiny shifts from which the absolute distance between the Sun and the Earth could be deduced. Once the Sun-Earth distance was known, the distances between all the other planets in the solar system could be inferred as well, by means of Kepler's Third Law. ${ }^{4}$

The stakes were thus nothing less than the very dimensions of the solar system and the place of the Earth within it. Excitement among contemporaries ran high, and no less considerable is the interest paid by modern scholars to what has been recognized as the greatest collaborative effort in eighteenth-century field science. ${ }^{5}$ Indeed, already in 1761 , at least 130 successful

3 Edmond Halley, "Methodus singularis quâ Solis parallaxis sive distantia à Terra, ope Veneris intra Solem conspiciendæ, tuto determinari poterit," PTRSL 29 (1714/16; printed 1717): 454-64. This was an elaboration of a paper read before the Royal Society in 1691, itself based on ideas conceived during Halley's observation of a transit of Mercury at the island of St. Helena in 1677 .

4 Kepler had found that "the squares of the times of revolution (periods) of the planets are proportional to the cubes of their mean distances from the sun" (quoted after Woolf, The Transits of Venus, 3). Whereas the times spent by each of the then known planets-Mercury, Venus, Earth, Mars, Jupiter, and Saturn - in encircling the Sun were known to Kepler, he could only guess at the distances between them. However, as soon as the distance between the Sun and any of the planets in the solar system was known, the size of the whole system could be deduced by means of this Third Law. For a discussion of the mathematical principles behind the Third Law, see A.E.L. Davis, "Kepler's Angular Measure of Uniformity: How It Provided a Potential Proof of His Third Law," in Miscellanea Kepleriana: Festschrift für Volker Bialas, ed. Friederike Boockmann, Daniel A. Di Liscia, and Hella Kothmann (Augsburg: Erwin Rauner Verlag, 2005), 157-73.

5 Historical accounts of past transits of Venus, with ample explanations as to how they were predicted, how they were used for computation of the solar parallax, how they were observed, 
observations were made at sixty-seven different places. The results being unsatisfactory, by 1769 the number of observational posts increased to seventyeight, producing at least 154 individual observation sets. ${ }^{6}$

More will be said about the reasons why and the complex ways in which the eighteenth-century Venus transit enterprise so faithfully reflected emerging notions about the simultaneously competitive and collaborative nature of scientific knowledge production in particular and social interaction in general in Chapters 5 and 6, dedicated to the Arctic expedition led by Hell in 1769. Here, it suffices to recognize that in a good measure thanks to the vast geographic spread (including exotic locations), a substantial part of the literature focuses on the historical significance of a particular expedition, region, or country. ${ }^{7}$

etc. are provided by, among others, Harry Woolf's standard The Transits of Venus as well as several more recent surveys, in no small measure occasioned by the 2004 transit. See Eli Maor,Venus in Transit (Princeton: Princeton University Press, 2004 [2000]); David Sellers, The Transit of Venus: The Quest to Find the True Distance of the Sun (Leeds: MegaVelda Press, 2001); Christophe Marlot, Les passages de Vénus: Histoire et observation d'un phénomène astronomique (Paris: Vuibert/Adept, 2004); Jean Eudes Arlot and Jean-Pierre Luminet, Le passage de Vénus (Les Ulis: EDP Sciences Editions, 2004); William Sheehan and John Westfall, The Transits of Venus (Amherst: Prometheus Books, 2004). Several proceedings of international conferences contain historical articles on the transits of Venus. Gotha in 1998: Peter Brosche et al., eds., The Message of the Angles: Astrometry from 1798 to 1998, Acta Historica Astronomiae 3 (Frankfurt: Harri Deutsch, 1998); Lancashire in 2004: Kurtz, Proceedings; Observatoire de Paris in 2004: David Aubin, ed., Lévénement astronomique du siècle? Histoire sociale des passages de Vénus, 1874-1882, Cahiers François Viète 11-12 (Nantes: Cahiers François Viète, 2007). For papers occasioned by the 2012 transit, see Journal of Astronomical Data, special issue, "Meeting Venus: A Collection of Papers Presented at the Venus Transit Conference in Tromsø 2012," ed. Christiaan Sterken and Per Pippin Aspaas, 19, no. 1. (Brussels: C. Sterken, 2013).

6 For a full list of the observation posts and the observers (as well as their instruments and sponsors) from both 1761 and 1769 , see Woolf, Transits of Venus, 135-40, 182-87; supplemented by Aspaas, "Maximilianus Hell," 211-18, 269-77.

7 Of the most-celebrated cases, on James Cook's Tahiti expedition, see, e.g., Derek Howse and Andrew Murray, "Lieutenant Cook and the Transit of Venus, 1769," Astronomy \& Geophysics 38 (1997): 27-30; Wayne Orchiston, "James Cook's 1769 Transit of Venus Expedition to Tahiti," in Kurtz, Proceedings, 52-66; on Chappe d'Auteroche's Siberia expedition, Michel Mervaud, ed., Voyage en Sibérie fait par ordre du Roi en 1761, 2 vols., Studies on Voltaire and the Eighteenth Century, 2004, no. 3, and 2004, no. 4 (Oxford: Voltaire Foundation, 2004); on Chappe d'Auteroche's California expedition, Doyce B. Nunis Jr., ed., The 1769 Transit of Venus: the Baja California Expedition of Jean-Baptiste Chappe d'Auteroche, Vicente de Doz, and Joaquín Velázquez Cárdenas de León, Baja California Travels Series 46 (Los Angeles: Natural History Museum of Los Angeles County, 1982); Iris H.W. Engstrand, "The Transit of Venus in 1769: Launching Pad for European Exploration in the Pacific during the Late Eighteenth Century," Boletin:Journal of the California Mission Studies Association 21 (2004): 36-48; on North America, Silvio A. Bedini, "The Transit in the Tower: English Astronomical Instruments in Colonial America," Annals of Science 54 (1997): 161-96, here 184-88; on William Wales's (c.1734-98) expedition, Don Metz, "William Wales and the 1769 Transit of Venus: Puzzle Solving and the 
Hell's Vardø trip was regarded in the eighteenth century as being almost as exotic, and certainly no less scientifically important, as those undertaken by James Cook (1728-79) to Tahiti in 1769 or by Chappe d'Auteroche to Tobolsk in 1761 and Baja California in 1769. For over a hundred years, his sets of data from Vardø featured prominently in debates about the distances of the solar system. The expedition and its scientific results, therefore, figure quite prominently in the scholarship. By contrast, the place of Vienna and Hell in 1761 is more of a footnote in the master narrative. Doing justice to them is not an exercise of merely antiquarian or self-serving interest, but indispensable to the argument of this book about the intertwining of personal agency in the local, regional, and transnational spaces where Hell exerted his talents.

Before providing an account of astronomical activity in the Habsburg territories during and in the aftermath of the 1761 transit, some technicalities need to be considered. The astronomical unit to be obtained from the Venus transit observations was based on the so-called parallax: the difference in the apparent position of an object against a background when viewed from different angles. The observation of the passage of the tiny disc of Venus, when viewed from different positions against the background of the Sun as various astronomers spread themselves over the Earth, made it possible to determine a parallax — called the solar parallax - provided that the distance between various observation sites was accurately measured, and the observers at each location properly kept the time. In sum, two sets of data were necessary: first, the geographical position of each observer, and second, the exact divergence of Venus's path in front of the Sun as seen from the various stations. The figure of the solar parallax was really just a compressed, internationally acceptable way of expressing the distance between the Earth and the Sun, without having to choose between English, French, or various German miles, the Russian verst, the French toise, or (later) the kilometer.

Determination of the Astronomical Unit," Science and Education 18 (2007): 581-92; on Australia, R.J. Bray, "Australia and the Transit of Venus," Proceedings of the Astronomical Society of Australia 4 (1980): 114-20; on the Dutch East Indies, Robert H. van Gent, "Observations of the 1761 and 1769 Transits of Venus from Batavia (East Indies)," in Kurtz, Proceedings, 67-73; on Ireland, C. John Butler, "Observations of Planetary Transits Made in Ireland in the 18th Century and the Development of Astronomy in Ireland," in Kurtz, Proceedings, 87-99; on France, Harry Woolf, Les astronomes françaises, le passage de Vénus et la diffusion de la science au XVIII ${ }^{e}$ siècle (Paris: Université de Paris, 1962); Jean-Claude Pecker, "Jérôme de Lalande and International Cooperation," in Brosche et al., Message of the Angles, 52-62; Suzanne Débarbat, "Venus Transits: A French View," in Kurtz, Proceedings, 41-51; on Scandinavia, Per Pippin Aspaas, "Nordiske amatørastronomers bidrag i forbindelse med venuspassasjene $1761 \mathrm{og}$ 1769," in Mellom pasjon og profesjonalisme: Dilettantkulturer i skandinavisk kunst og vitenskap, ed. Marie-Theres Federhofer and Hanna Hodacs (Trondheim: Tapir, 2011), 103-27. 
A planetary transit can only occur with either of the two planets Mercury and Venus, since the other planets in our solar system have orbits farther out, thus never passing between the Sun and the Earth. However, although transits of Mercury occur fairly frequently (between twelve and fourteen times a century), they are of little use in calculating the solar distance. Mercury is simply too close to the background (the Sun) to offer any substantial parallax, no matter how far apart the terrestrial observers spread themselves. ${ }^{8}$ The planet Venus, on the other hand, orbits the Sun much closer to the Earth and should therefore be of far better use, according to the ideas of influential eighteenthcentury astronomers.

A transit may last for several hours, depending on how close to the center of the Sun's disc the planet makes its passage. As a result of parallax, the time spent by the planet crossing the disc of the Sun will also vary according to where on the surface of the Earth an observer is situated. The transit of Venus in 1769 , for example, as observed by Hell in Vardø, lasted $6^{\mathrm{h}} 29^{\prime} 34.5^{\prime \prime}$ (six hours, twenty-nine minutes, thirty-four-and-a-half seconds). At the same time, astronomer Charles Green (1735-71) of Cook's crew on Tahiti saw Venus spend $6^{\mathrm{h}}$ $5^{\prime} 37^{\prime \prime}$ crossing the Sun (i.e., nearly twenty-four minutes less). ${ }^{9}$ This difference in time was a key figure in the calculation of the Sun's parallax. By measuring the exact time spent by Venus in crossing the Sun, astronomers were able to determine how close to the center of the Sun's disc the transit took place as seen from each station. Theoretically, the position of Venus on the Sun's disc could be measured. In practice, such observations turned out to be difficult, and the displacements of Venus insufficiently large to yield a satisfactory result. Exact time-keeping, combined with the determination of each observer's geographical position, therefore came to constitute essential data for the calculation of the solar parallax (see fig. 4).

The crucial stages of the transit were the moments of contact between Venus and the limb of the Sun, commonly designated as the exterior and interior contact of ingress, and the interior and exterior contact of egress, sometimes referred to in order of appearance as the first exterior, first interior, second interior, and second exterior contacts, or sometimes just first, second, third, and fourth contacts (see fig. 5 )..$^{10}$ It was the two interior contacts, that is, the second and third contacts, that were of primary concern to Halley. But what if cloudy

8 See, e.g., Woolf, Transits of Venus, 35-51; Marlot, Les passages de Vénus, 92, 99.

9 Duration of the entire transit as reported by Hell, Observatio transitus Veneris [...] Wardoëhusii [...] facta [...] 1770, 78-80, and by Charles Green in James Cook, "Observations Made [...] at King George's Island in the South Sea [...]," PTRSL 61, no. 1 (1771; published 1772): 397-421, here 410.

10 The terms immersion and emersion are also used as synonyms for ingress and egress respectively (immersio and emersio in Latin literally mean "diving in" and "diving out," 


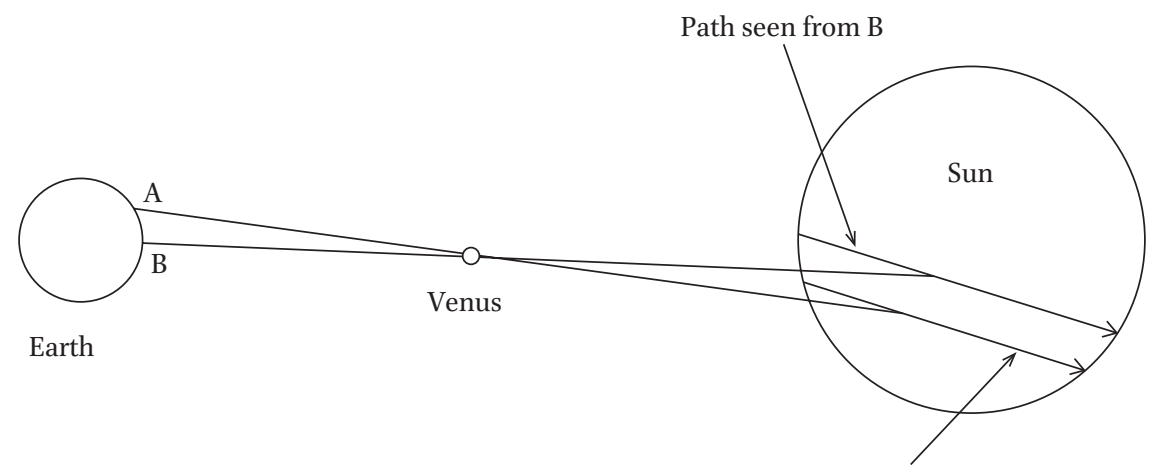

Path seen from A

FIGURE 4 The shift of Venus's path from two sites of observation

During a transit of Venus, the path of the planet on the disc of the Sun as seen from A and B would shift, altering the times of ingress and egress as well as the total duration of the transit (note that the degree of shift has been exaggerated here). Illustration and accompanying text by Truls Lynne Hansen

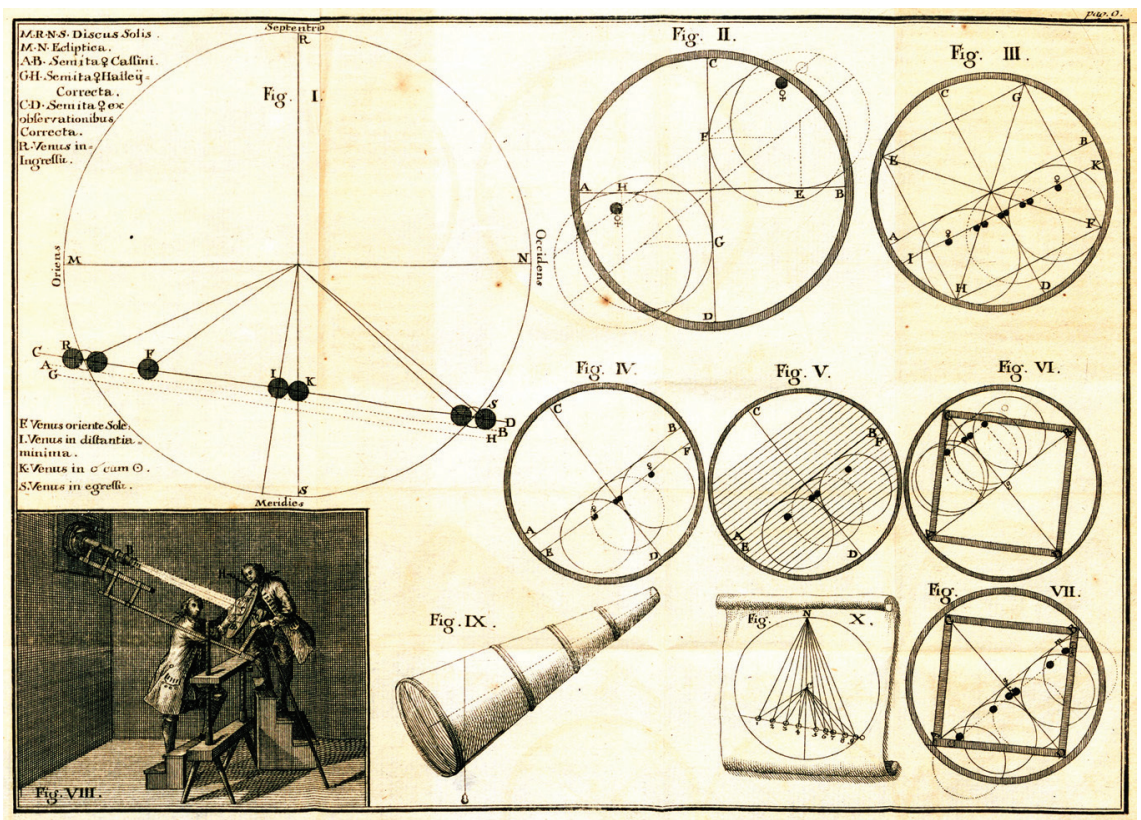

FIgURE 5 From Hell's manual Transitus Veneris per discum Solis Anni 1761

Upper left (fig. I.) shows the black spot of Venus at various stages during its transit in front of the solar disc. The crucial moments of contact with the limb of the Sun are clearly marked (the two pairs of contact at ingress and egress are tagged as $\mathrm{R}$ and $\mathrm{S}$ respectively). Lower left illustrates the use of a camera obscura, with which laymen equipped with fairly modest instrumentation could trace the transit on a sheet of paper. Digitized by the Department of Astrophysics, University of Vienna 
weather deprived an observer of one of these crucial contacts, or a station's geographical position made only the ingress or egress of a transit observable? Following Halley's method, precious data from many stations were at risk of having to be discarded. This concern was raised by Delisle, the "grand old man" of European astronomy and a leading figure in the planning of the Venus transit project of 1761 , since Halley himself had passed away in 1742. In various memoirs, articles, letters, and unpublished lectures, Delisle presented an alternative method for the computation of the solar parallax. If a single contact of Venus with the Sun's limb was observed from two stations ranging far apart, he argued that the difference in latitude and longitude between the two stations would provide the necessary basis for the computation of the parallax. ${ }^{11}$ This suggestion no doubt came as a relief to many astronomers on the European continent. The transit of 1761 was pre-calculated to take place during the night and early morning hours as seen from the heartland of Europe, leaving hope only for the egress (i.e., the end stages of the transit) to be observed. By following Delisle's method, however, data from these observatories would be just as valuable as those from faraway places on other continents.

This is where Hell saw his golden opportunity. Although no expeditions overseas were planned by the Habsburg monarchy, which lacked territories in which the entire duration of the coming transit would be visible, it was still possible - thanks to Delisle's modification of Halley's idea-for the Imperial and Royal Observatory of Vienna to provide the global community of astronomers with crucial datasets for the calculation of the solar parallax. And not only that, Hell could employ his prestigious title of imperial and royal astronomer in combination with his budding fame as editor of the only official astronomical yearbook apart from France's Connoissance des temps to organize observations all over the Habsburg lands and beyond. This is exactly what he did.

A concrete step to facilitate this was the publication of a twenty-page printed instruction, written by Hell, explaining how the transit should be observed. Written in a language accessible even to those with relatively little previous

ingressus and egressus "going in" and "going out"). Furthermore, internal and external are common synonyms for interior and exterior.

11 In one of his manuscripts, read as a memoir to the Royal Academy of Sciences in Paris, April 30, 1760, Delisle explains: "This method consists of using observations of the entry or exit [of Venus] at places where one of these two stages will take place at points of time differing as much as possible between them." Jean-Eudes Arlot, ed., Les rendez-vous de Vénus/Venus's rendez-vous, CD-ROM (Les Ulis: EDP Sciences, 2004), caption Delisle, manuscrits 1753 et 1760,10 . See also Woolf, Transits of Venus, 33-35. 
experience in astronomy, this illustrated manual ${ }^{12}$ was widely disseminated, even well beyond the Habsburg territories (see fig. 5). In parallel, Hell offered assistance with the placing of orders at the instrument-makers of Vienna, thereby forging new - and consolidating existing — contacts with professionals as well as amateurs of science. ${ }^{13}$ An underlying strategic scheme was set in action: this was an opportunity not only for Hell personally but also for Vienna as a "capital of science," and not least for the Austrian province of the Society of Jesus, to manifest itself as a fully integral part of the contemporary Republic of Letters, with its ideological focus on "utility" and the expansion of knowledge through the dissemination of scientific practices to an ever-growing segment of society.

Nowhere in the existing sources is Hell more outspoken on these aspects than in a letter to Christian Rieger (1714-80), who had just left a professorship in Vienna to teach mechanics, astronomy, and other exact sciences at the Colegio Imperial in Madrid. Rieger was one of the Austrian Jesuits who found a career opportunity within the order outside their native province. He was born in Vienna and entered the Society of Jesus in 1731. Having taught for a while, probably at gymnasium level, in Gorizia (Goritia, Görz), he received his first chair as a professor of architecture at the Theresianum in 1748, before switching to experimental physics in the period from 1753 to 1756 . Probably as an extension of this, Rieger was employed briefly as the prefect of the Museum Mathematicum in $175^{6-57}$, but for the university years 1757 to 1760 he was a professor of mathematics in Vienna. Whether he was called upon or sought himself to go elsewhere is unclear, but in 1760 he made a giant leap to Madrid, where he taught mechanics, mathematics, physics, and astronomy at the Colegio Imperial until 1765 . In the 1750 s and 1760 s, Rieger published textbooks on architecture in Latin and Spanish, as well as a handful of works on astronomy and experimental physics, including electricity. Rieger observed the transit together with Spanish colleagues, and published a report in Spanish that was also summarized in Hell's Ephemerides. In 1765, Rieger returned to the Austrian province to become rector of the Jesuit college in Passau and then Ljubljana. After the suppression of the Society, he resumed his teaching at the

12 Maximilian Hell, Transitus Veneris per discum Solis anni 1761: Die Astronom. 5. Junii calculis definitus et methodis observandi illustratus (Vienna: Trattner, 1760), also distributed along with most copies of the Ephemerides for the year 1761.

13 See, e.g., Hell to Christian Mayer in Heidelberg, February 9, March 12, and April 10, 1761; Hell to Ximenez in Florence, February 18, 1761; Freyherr von Ehrmans zum Schlug to Hell in Vienna, dated Wezlas, May 8, 1761 (all wus). 
Theresianum, though he no longer taught astronomical subjects. ${ }^{14}$ In his letter to Rieger, Hell states:

The method of observing the transit of Venus across the disc of the Sun you have access to in my printed Ephemerides. However, since I obviously lack the funds needed to distribute my Ephemerides to every single one of my correspondents (who are really quite numerous), I have decided to make a separate edition of my treatise Transitus Veneris per discum Solis, six copies of which are here enclosed for you to distribute among your correspondents. ${ }^{15}$

We see here a new node of science in action. Given the strategic importance of the transit of Venus, the Ephemerides alone could no longer suffice: Hell employed further means (printing and distributing a manual) to awaken interest in this particular observation. In a scientific culture permeated by the principle of "favor for favor," an implicit message in the distribution of the give-away copies was that recipients were more than welcome to report back to the author what they observed.16

In the same letter, misguided notions of scientific inferiority in regard of the Jesuits of the Austrian province are jealously combated:

Father Liesganig, who sends his greetings, hopes to be able to finish his measure of a degree of meridian by the beginning of this summer.

14 On Rieger, see the entries in Fischer, "Jesuiten-Mathematiker in der Deutschen Assistenz," and in Wurzbach, Biographisches Lexikon (1874), 26:113; for the Madrid years, Agustín Udías, "Los libros y manuscritos de los profesores de matemáticas del Colegio Imperial de Madrid, 1627-1767," Archivum historicum Societatis Iesu 74 (2005): 369-448; Victor Navarro Brotón, "Science and Enlightenment in Eighteenth-Century Spain: The Contribution of the Jesuits before and after the Expulsion," in O'Malley et al., Jesuits, 2:390-404.

15 Hell to Rieger in Madrid, February 6, 1761 (wUs).

16 Similar wording is found in a wide range of letters from January until March 1761; e.g., Hell to Lacaille in Paris, January 31, 1761; Hell to Braun in St. Petersburg, February 8, 1761; Hell to Christian Mayer in Heidelberg, February 9, 1761; Hell to von Condie, March 2, 1761 (all wUs). Also, comments on the Transitus Veneris manual were uttered in letters to Hell by Christian Mayer in Heidelberg, April 17, 1761; Lacaille in Paris, April 18, 1761; Messier in Paris to Hell, [May] 1761; Poleni in Padua, May 25, 1761 (all wUs). In his letter to Lacaille, dated January 31, Hell says his work was meant solely for learners in astronomy: "The copies of the Transitus Veneris per discum Solis you may distribute as you will among learners of astronomy, it is for their sake only that I decided to write it." That many observers were inspired by the reception of this manual to report their Venus transit observations back to Hell is seen in the report he subsequently compiled and issued as an appendix to the Ephemerides for the year 1762 (more on this below). 
Possibly, he will receive assistance in this endeavor from Father Boscovich, whose arrival among us is awaited any day soon. If this turns out to be the case, then our court—along with the rest of our adversaries—will surely be confirmed in their opinion, which we hear uttered every day, that the Jesuits of this [i.e., the Austrian] province are ignorant of the sciences. Surely, in case I had been in Father Liesganig's shoes, I would either have refused to accept help from a foreign province, or refused to take upon my shoulders such a burden, barely sustainable even for the greatest of men.

That Liesganig succeeded, and without the help of Boscovich at that, is another story altogether. ${ }^{17}$ What is of interest is that Hell's care for the prestige of Jesuit astronomy — with geodesy as a related field—did not restrict itself to the Austrian province alone. Further on in the same letter, the honor of the Habsburg capital is defended, exactly like Hell had been ordered in his instruction when appointed several years earlier:

Monsieur Chappe [d'Auteroche] stayed here for a few days until he left us on January 9 to go to St. Petersburg, from where he will proceed to Tobolsk. He was astonished to see how well equipped we are, both at the observatory of the [Jesuit] collegium and at my own. He asked me whether there were any lay practitioners of this science around. When I confirmed this, he retorted that astronomy in this city of ours was held in no esteem whatsoever among foreigners. Overall, during the few days that he stayed in this city he had experienced that, apart from the Jesuits and Prince Liechtenstein, all other persons he had met were fairly ignorant of the hard sciences. [...] This extremely friendly gentleman intends, on his return from Muscovy, to pay a visit to the mines of Hungary, in case this is allowed him by the academy [i.e., the Académie des Sciences], and I will gladly join him.

Thus, in his personal encounter with a Venus transit expeditionist commissioned by the Académie des Sciences, Hell's "cultural capital" as the scion of a family of mining engineers is brought to the fore, alongside his role as a "nodal astronomer," inspiring laymen to engage in the noble art of astronomy. His care for the reputation of the Society's Austrian province and the Habsburg capital go hand in hand.

17 See above, $123-25$. 
The Venus transit projects of the 1760 os have been described as the first ever instance of large-scale international cooperation in science, ${ }^{18}$ despite them taking place amid unprecedented scales of great power rivalry-in 1761, actually at the climax of the Seven Years' War-with the two leading nations of astronomy, France and Britain, at the helm of rival coalitions. While astronomers themselves managed to cooperate, the military events created some contingencies and disruptions: the French astronomer Guillaume le Gentil de la Galaisière (1725-92), for instance, set out to carry out the observation from the fortified town of Pondicherry on the Coromandel Coast in Southeast India, but before his arrival the town fell to the British who razed it to the ground. (Thanks to the 1763 Treaty of Paris, by the 1769 transit the town was in French hands again; Le Gentil duly returned and constructed a small observatory among the ruins of the former governor's palace, to be thwarted this time by the clouds.) Despite such difficulties, the number of successful endeavors was quite impressive. A mappemonde indicating where the transit would be visible had been issued by French astronomers and given worldwide distribution ahead of the transit, ${ }^{19}$ and in 1761 astronomers - most of them British and Frenchtook up positions in places as exotic as Tobolsk in Siberia (Chappe d'Auteroche), Jakarta in the Dutch Batavia (Johan Maurits Mohr [1716-75]), and St. Helena in the Southern Atlantic (Nevil Maskelyne [1732-1811]).

The informal center of coordination lay in Paris, where senior astronomer Delisle, assisted by his colleagues Messier, Cassini de Thury, Lacaille, and Lalande (all characters with whom Hell corresponded regularly), were pulling the strings. They were all active in the planning of the project, distributing

18 "The conjunction of enlightened interest and scientific practice, actually achieved in the observations of the transits, also gave rise to the first international, co-operative scientific expeditions in modern history." Woolf, Transits of Venus, 4. Others include the project of cartography, mentioned above, between Vienna and Paris that started in 1761, on the initiative of Cassini de Thury, as one of three international projects of cooperation in eighteenth-century science - the other two being the Venus transit project of the $176 \mathrm{os}$ (counted as a single project) and the Societas Meteorologica Palatina of Mannheim, founded in 1780. See Moutchnik, Forschung und Lehre, 18. The cartographical project of Cassini de Thury, however, included far fewer participants from a limited area and cannot be compared to the universal interest invested in the Venus transit project from the entire scientific community. A similar, small-scale but international undertaking of much greater geographical distribution than Cassini de Thury's cartography project would be the lunar parallax project of $175^{-} 5^{2}$, in which several astronomers from at least five countries took part (see further Aspaas, "Maximilianus Hell," 223-24.).

Reprint in Woolf, Transits of Venus, fig. 8, 98-99, cf. the distribution list, 209-11. 
scientific papers and letters containing practical counsel and encouragement to astronomers both in French provinces and abroad, and making arrangements that enabled their colleagues to obtain the best astronomical equipment available. Consequently, in the days, weeks, and months after the 1761 transit, observations came trickling in to the Académie des Sciences in Paris for the academicians to assess, adjust, and publish. Another center that received numerous Venus transit reports was the Royal Society in London, where a series of articles was subsequently printed in the society's Philosophical Transactions. Accordingly, the 1761 Venus transit enterprise figures in most accounts as a predominantly Franco-British story. However, a third center also contributed quite significantly to the instigation, organization, and subsequent publication of Venus transit observations all over the world: the Imperial and Royal Observatory of Vienna.

Perhaps more important than Hell's personal participation in the 1761 Venus transit observations is the brokerage role he played in the encounter, which naturally did not come to an end with his contributions to the preparatory moves, but loomed especially large with the subsequent collection and publication of data. The greatest public display of the imperial astronomer's network to date-or, more specifically, of his role as an inspirer, organizer, and publisher of observations-emerged in the autumn of 1761 , in the form of a 124-page report: "Observation of the Transit of Venus in Front of the Disc of the Sun on June 5, 1761, with Observations of the Same Venus Transit Made by Various Skilled Observers throughout Europe, and an Appendix of Several Other Observations," published as an appendix to the Ephemerides for the year $1762 .{ }^{20}$ Internal evidence indicates that it was printed some time during the autumn of 1761 , the last dated reference in the text being to August of that year. ${ }^{21}$ By then, Hell had received letters and printed reports stating the results of observations in Central Europe as well as Russia, Sweden, Italy, France, Spain, and even England, despite the war. Several observers referred to Hell's handy little manual when they reported their observations. ${ }^{22}$ The ability of Vienna, and the Austrian province of the Society of Jesus in particular, to provide scientific

20 Maximilian Hell, "Observatio transitus Veneris ante discum Solis die $5^{\text {ta }}$ Junii $1761[\ldots]$ : Adjectis observationibus ejusdem transitus Veneris factis à variis per Europam viris in observando exercitatis, cum appendice aliarum nonnullarum observationum," Ephemerides $1762(1761)$.

21 Hell, “Observatio transitus Veneris [...] 1761," 89: "Anno 1761. [...] mense Augusto." Unfortunately, we have been unable to track down letters written in the autumn/winter of 1761-62 that might have shed light on the exact date of publication.

22 Cf. Hell, "Observatio transitus Veneris [...] 1761," 89, where Hell states his sources for the data of other observers scrupulously. Many of the handwritten reports on the 1761 transit 
observations of global significance was no longer questionable. At the helm of it all, incidentally, was the Jesuit Maximilian Hell. Not all observers reported directly to the astronomical giants of Paris and London. Some shared their data with Hell, leaving it to him to assess and publish their observations.

The report included in the Ephemerides for the year 1762 was not the only instrument of promoting Hell's (and Vienna's) reputation. As already mentioned, around the time of the 1761 transit of Venus, the scholarly community in Vienna received prominent visitors from Paris: following Chappe d'Auteroche's visit en route to Siberia in January, the director of the Observatoire Royal, Cassini de Thury, arrived in mid-May. Principally on a geodetic mission sponsored by the two new diplomatic and military allies, France and the Habsburg monarchy, Cassini de Thury stayed long enough to observe the transit of Venus in the early morning hours of June 6 from Liesganig's observatory. Cassini de Thury already held Hell in high esteem, and the reason for his choice of location is probably as simple as given in his own account of his trip: the Jesuit observatory was "preferable to that of Father Hell because of its situation and because of the abundance of instruments." ${ }^{23}$ While it was Hell who bore the title "imperial and royal," the dynasty chose to follow Cassini de Thury in honoring the Jesuit observatory with the presence of one of its members. As Cassini de Thury reports:

As I was waiting for the reappearance of the Sun impatiently, [...] the august archduke Joseph [arrived], who left Laxenburg at four o'clock in the morning in order to witness my observations; luckily, the Sun revealed itself again, and this prince looked at Venus several times, and posed me several questions that testified to the range of his knowledge. ${ }^{24}$

that were delivered to Hell are still preserved among his manuscripts at the Universitätssternwarte Wien.

23 César-François Cassini de Thury, Relation de deux voyages faits en Allemagne par ordre du Roi: Par rapport à la figure de la Terre [...] Par rapport à la geographie [...] Par rapport à l'astronomie [...] (Paris: Durand, 1763), xiv. Cassini de Thury's appreciation for Hell as a colleague who has "given great proofs of his competence and exactitude in the practice of astronomical observations" is expressed on viii. On the location, cf. also Cassini de Thury, "Observation du passage de Vénus sur le Soleil, faite à Vienne en Autriche," Histoire de l'Académie Royale des Sciences 1761 (published 1763): 409; Hell, "Observatio transitus Veneris $[\ldots]$ 1761," 17-20, 41. The claim that Cassini de Thury observed the transit "from the comfortable quarters of the Vienna Observatory" in the company of "the observatory's director, Father Maximilian Hell" (Maor, Venus in Transit, 87, repeated in Wolfgang Steinicke and Wilhelm Brüggenthies, "Maximilian Hell und der Venustransit von 1769: Eine abenteuerliche Reise nach Vardø," VdS-Journal 15 [2004]: 78-81, here 78) is mistaken. 
The imperial heir's attendance at the Jesuit observatory confirms the status of Cassini de Thury's journey as not only a scientific one but a visit of first-rate diplomatic significance. It also involved meetings with top decision-makers like Kaunitz, and an audience with Maria Theresa herself, who lavished on the astronomer such honors that "I can hardly comprehend, still less am I able to express." 25

Despite the fact that in Hell's observatory high buildings nearby blocked part of the view to the east, where the rising Sun was expected to display Venus as a tiny spot on its disc, three observers were present at that site- the Viennese professor of physics, Joseph Herbert (Herberth [1725-94]) of the Society of Jesus, along with two of Hell's students. The imperial astronomer himself, however, took up his position in a tower of the nearby Jesuit library. ${ }^{26}$ All these sites of observation lay within a few hundred meters of each other and provided the astronomical community with independent data from a total of nine observers from virtually the same geographical point. ${ }^{27}$ What is important to note, however, is that - with the single exception of Liesganig — none of the professional observers in Vienna managed to observe the interior contact of egress, due to clouds. All they could see were parts of the planet's path across the Sun's disc, as well as the moment of exterior contact.

Returning to Hell's report, the general failure to observe the interior contact at ingress in Vienna did not render the observations futile. Altogether, thirtytwo pages are devoted to the observations in the Habsburg capital and the conclusions drawn from them. On the level of scientific prestige, Hell's scheme arguably entailed a massive success. In his letter to Rieger, quoted above, Hell confessed that he found Chappe's comments on the seeming ignorance of astronomy among the Viennese disturbing. Not surprisingly, in his report he goes to some lengths when reporting the endeavors of the local amateurs introduced in Chapter 2. Sambach took up position on the top of his house in the suburb of Spittelberg "with a seven-foot telescope fabricated by himself and instructed by me with a micrometer, mounted on a stand that resisted all kinds of motion, and having moreover a pendulum clock to hand," but failed to see anything whatsoever of the crucial contacts due to clouds. ${ }^{28}$ The "highly illustrious Mr. Müller" was prepared to observe in the St. Leopold district, with his

\footnotetext{
25 Cassini de Thury, Relation de deux voyages, xi.

26 Hell, "Observatio transitus Veneris [...] 1761," 1-20, here 1.

27 The authors are indebted to Prof. Maria G. Firneis of the Institut für Astrophysik at the University of Vienna for information concerning the positions of these historical sites (guided tour during the conference "Astronomie in Wien: 250 Jahre Eröffnung der Universitätssternwarte," September 29-October 1, 2006).

28 Hell, "Observatio transitus Veneris [...] 1761," 20-21.
} 
three-foot telescope equipped with a micrometer and a lens that he himself had darkened. However, according to Hell, Müller's observation of the final contact of Venus with the limb of the Sun was not exact enough, "probably because the correction of the clock's time-keeping had not been made in the way it should."29 The third amateur mentioned by Hell was an anonymous merchant (Mercator quidam), who had observed the transit in a suburban garden, using "an exquisite telescope." However, since this merchant had no more than the public clock (indicating only the minutes, not the seconds) at his disposal, his successful observation of both the interior and exterior contact at egress was of little scientific value. ${ }^{30}$

The rhetorical value of the account of these Viennese amateurs, none of whom had contributed anything of substance, worked in tandem with another public purpose: that of demonstrating the capability of members of the Society of Jesus, and of the Austrian province in particular, to instigate, coordinate, and publish scientific observations. In the historiography of the transits of Venus, the Jesuit involvement has generally not been emphasized. A closer look at Hell's report gives ample reason to reconsider the master narrative, in which the Venus transit projects of the 1760 are depicted as predominantly FrancoBritish — and secular - endeavors. Hell's text is partitioned according to the designations Germania (including Austria), Gallia (France), Anglia, Hispania, Italia, Hungaria, Polonia, Svecia (Sweden, including Finland), and Moscovia (Russia). Yet this seemingly innocent division conceals a bias, which merits some consideration. No deconstruction can, however, take away from Hell his success in demonstrating the important contributions of Jesuit science, and of Vienna as a capital, to the international Venus transit project of 1761 .

Alongside the above-mentioned Jesuit professor Herbert, the transit was observed in the imperial observatory by Hell's assistant, the Jesuit magister Ignaz Rain (dates unknown), titled repetens matheseos (assistant teacher of mathematics). At their side was the young canon Dominik Lysogorski, who had been sent to Hell as a student by the archbishop of Lviv in 1758 or $1759 \cdot{ }^{31}$ Having

29 Hell, "Observatio transitus Veneris [...] 1761," 21.

$30 \quad$ Hell, "Observatio transitus Veneris [...] 1761," 21.

31 Hell, "Observatio transitus [...] 1761," 17. Lysogorski's identity is somewhat obscure. Several years later, in a letter to the bishop of Eger, Károly Eszterházy (cf. above, 129-30), Hell mentions that a priest by the name of Lysogorski had been sent in 1758 to study mathematics with him by the archbishop of Lviv, Wacław Hieronim Sierakowski (1700-80). Hell to Eszterházy in Eger, Vienna, February 17, 1777. FLE, AV, 2629; in Hell, "Observatio transitus [...] 1761," 89, the year 1759 is stated. In a letter to the professor of geography at the College Royal (now Collège de France) in Paris, Hell explains that "the friar Lysogorski [...] lived in my observatory as a guest for two years, where I instructed him in both kinds of 
spent more than two years in Hell's observatory, Lysogorski left Vienna soon after the observation of the transit with the intention to lay the foundations for an astronomical observatory at his home university of Lviv, which-as Hell was careful to remark-already hosted a decent number of Jesuit professors. ${ }^{32}$ Lviv belonged at the time to the Kingdom of Poland-Lithuania. Only one publicly known observation from this realm-namely from Kraków-was mentioned by Hell, who suppressed the identity of its author and without further ado rejected it as "highly imperfect" (valde imperfecta)..$^{33}$ The hope for the future there lay entirely with the Society of Jesus: not only was (the Jesuit-taught) Lysogorski in place at the (Jesuit-dominated) university of Lviv but also

two mathematicians of our Society have been called from France, the professors Rossignol and Fleuret, who will begin to cultivate astronomy in Vilna [...]. It is therefore to be hoped that, with these three men in place in Poland - which thus has in its ranks intellects no less brilliant than those of other kingdoms - a substantial number of new astronomers will be created. ${ }^{34}$

In this way, two entire pages are spent on Poland, without any transit observations whatsoever being reported from there.

The Jesuit aspect is similarly emphasized in other regions within the Habsburg monarchy and its sphere of interest. Given Hell's later expressions of patriotism on behalf of his Hungarian patria, the subchapter titled "Observatio Tyrnaviensis in Hungaria (Observation of Trnava in Hungary)" is surprisingly

astronomy [i.e., both theoretical and practical]. In July of this year, he returned to Poland with the necessary instrumentation; we expect very good observations from him in the future." Hell to Zannoni in Paris, dated Vienna, December 16, 1761. Transcript of the original made by Bigourdan, kept at the Bibliothèque de l'Observatoire de Paris.

32 Hell, "Observatio transitus [...] 1761," 17, 89-90.

33 The printed report in question was surely Jakub Niegowiecki, Transitus Veneris per discum Solis post peractas revolutiones tam synodicas quàm periodicas intrà annos circiter 122. iterum anno domini 1761. die 6. Junii. celebratus et per mathematicos universitatis Cracoviensis sub elevatione poli gr. 50. min. 12. observatus (Kraków, 1761), cf. Barbara Bieńkowska, "From Negation to Acceptance: The Reception of the Heliocentric Theory in Polish Schools in the 17th and 18th Centuries," in The Reception of Copernicus' Heliocentric Theo$r y$, ed. Jerzy Dobrzycki (Dordrecht: Reidel, 1972), 79-116, here 88-89.

34 Hell, "Observatio transitus Veneris [...] 1761," 89. As for the two characters, Rossignol and Fleuret, we have failed to find more information. They certainly do not figure in the official lists of Jesuit mathematicians working at the Collegium Vilnense during the eighteenth century. Karl A.F. Fischer, "Die Jesuiten-Mathematiker des Nordostdeutschen Kulturgebietes," Archives internationales d'histoire des sciences, 34 (1984): 124-62, here 133-34. 
brief, merely four-and-a-half pages. ${ }^{35}$ Here, Hell exclusively reports the observations of his confrère Weiss in Trnava, without even mentioning the existence of able observers such as the Calvinist Hatvani or the Lutheran Schumacher in the same territory. Instead, the imperial astronomer is careful to extol the Trnava university as an institution run entirely by the Society of Jesus. At the end of this account, he explains that Weiss has already shared the details of his Venus transit observation with the illustrious Cassini de Thury, "when he, accompanied by myself, visited the observatory in Trnava [i.e., shortly after the transit had taken place]." Furthermore, Hell himself made sure to dispatch a transcript of Weiss's observation to Lacaille in Paris, "for him to include in his collections." ${ }^{36}$ The message resonates clearly: the one and only Jesuit-run observatory in Hungary is fully integrated in the Republic of Letters; any activity by scholars belonging to other denominations is not worthy of mention.

A longer subchapter entitled "Observationes per Germaniam factae," or observations made throughout the German-speaking parts of Europe, gives further evidence of confessional as well as imperial concerns. ${ }^{37}$ The abovementioned amateur, Baron zum Schlug, is accorded no fewer than six pages, consisting of full length quotations from a letter addressed to Hell, followed by the imperial astronomer's corollary:

If only the brightest of intellects, the kind of which our flourishing territories $[\ldots]$ are teeming with (in much the same way as France, England, Italy, etc.), would become inspired by this uniquely illustrious nobleman's example to engage both in astronomical works, worthy as they are of the capacity of sublime minds, and in activities more useful than any other pastime! ${ }^{38}$

Next in line after the illustrious Austrian baron, we find seven-and-a-half pages devoted to the Jesuit Georg Kratz (or Kraz [1713-66]) of Ingolstadt (taken from a letter); two pages consisting of a summary of a printed report by an anonymous team in the Catholic stronghold of Munich; two pages with a similar summary of a printed report by Hell's associate, the Jesuit Franz Huberti in Würzburg; and two-and-a-half pages on yet another associate, the Jesuit Christian Mayer, who observed the transit in the company of Prince-Elector Charles Theodore (1724-99, r.1742-99) in Schwetzingen (a letter is here again the

35 Hell, "Observatio transitus Veneris [... 1761," 84-89.

36 Hell, "Observatio transitus Veneris [...] 1761," 88.

37 Hell, "Observatio transitus Veneris [...] 1761," 62-84.

38 Hell, "Observatio transitus Veneris [...] 1761," 67. 
source). A brief, less than half-page mention of the Jesuit philosophy and mathematics professor Berthold Hauser (1713-62) in Dillingen is then included (source not given), followed by less than a page on Tobias Mayer in Göttingen and the Dresden amateur Christian Gotthold Hoffmann (1713-78), respectively. Finally, half a page on the Jesuit Johann Baptist Schöttl (1724-?) in Ljubljana rounds off the account of "German" observations of the 1761 transit. Or not quite: Hell also mentions that the Jesuit father Stepling in Bohemian Prague has seen nothing due to clouds. The message is again clear. Jesuit and Catholic observers from Germania have been found worthy of a good twenty pages, including some cases when they have not seen anything whatsoever, whereas observers of other creeds-even someone as famous as Tobias Mayer-are hardly noticed. A curious omission from the report is the university observatory of Graz, with which relations of the Jesuit astronomers of Vienna were lukewarm. Another omission is the high-standard observatory of the Benedictines at Kremsmünster, where the transit was indeed observed. ${ }^{39}$ The absence of Graz and Kremsmünster in the report does not spoil the general picture, however.

Much of the material forming the basis of Hell's report has been found among his surviving manuscripts in Vienna. Included there is a fine original drawing of the path of Venus across the Sun's disc as observed by Hoffmann, a Lutheran finance officer in Dresden. Hoffmann was an enthusiast of natural inquiry, with an avid interest in botany, geology, and meteorology; nor was he ignorant of astronomy, having also observed Halley's Comet in 1759. In his polite, less-than-one-page mention of Hoffmann in the printed report, Hell describes him as "a man already famous, thanks to other observations made in the same city" and characterized by "a singular friendliness toward men of learning." However, the account is soon cut short by the remark that in Dresden "the egress could not be exactly observed due to clouds." ${ }^{40}$ Curiously, there is no mention of clouds in the illustrated manuscript in Hoffmann's own hand, which is preserved among Hell's manuscripts. ${ }^{41}$ Even the exact moment of interior contact at egress is recorded. Perhaps the account of bad weather was

39 According to the website www.transitofvenus.nl/history.html edited by Steven van Roode (accessed via the Wayback Machine at https://web.archive.org [June 1, 2019]), Fixlmillner's predecessor Eugen Dobler observed the transit "accompanied by prelate Bertholdi and other clergymen." As for Graz, the Ephemerides did not publish observation results from there regularly until 1767 . Before then, the only instance was a report on a lunar eclipse of March 17, 1764 by Poda's successor Karl Tirnberger (1732-80), prefect of the Graz observatory from 1764 to 1771 .

40 Hell, "Observatio transitus Veneris [... 1761," 82-83.

41 wUs. 
found in some-now lost—accompanying letter. Another possibility is that Hell was deliberately brief and dismissive regarding the reliability of Hoffmann's observation. After all, this "friendly" colleague was not only Lutheran but a high-profile propagandist at that: Hoffmann was the man who in 1756 published the account of Johann Ludewig, the "learned farmer" in Protestant Saxony, to which Hell and Weinhart offered their portrait of Peter Anich as a Catholic counterpart. ${ }^{42}$

Preceding the twenty-two pages on Germany, there are thirteen pages covering "observations made in Italy."43 Again, Hell's Jesuit network emerges from these pages clearly. In Bologna, a group dominated by Jesuit astronomers and spearheaded by the observatory director Zanotti had produced a report that Hell reprinted, interspersed with his own comments, over nearly six pages. Similarly, two-and-a-half pages from a printed report by Leonardo Ximenez (1716-86) in Florence was found worthy of insertion. Again, the depiction of cutting-edge observational astronomy as a largely Jesuit affair is striking. The sheer amount of space devoted is quite spectacular, given that several places, such as Padua (where a substantial group of Jesuits had prepared themselves) and Venice (where perhaps the most famous of all, Boscovich, was present), had overcast weather. Furthermore, some places had not yet submitted any report to Vienna, such as Milan, where - as Hell points out-a team of Jesuit astronomers ran the famous Brera Observatory. One may interpret this namedropping as a sign of Hell's eagerness to demonstrate the importance of Jesuit science to the project. The close political and dynastic relations between Habsburg-ruled Vienna and various Italian territories may also have influenced the imperial astronomer's account.

In Hell's 1761 transit of Venus report, we find that Jesuit, Catholic, and imperial concerns manifest themselves both in the selection of materials and in the space and nature of the commentary dedicated to the various observations. These concerns are mostly recognizable in regard of Habsburg, or at least Holy Roman, territories. The bias is less conspicuous, it partly even dissipates, as the concentric rings move farther away from Vienna. France is extolled as "the highly fertile parent and nurse of the most eminent astronomers of our age" and the Académie des Sciences as a "mother of astronomers." 44 Over the sixpage coverage of Gallia, there is no particular Jesuit coverage. The emphasis on nobility and Catholicism, so visible in the account from Germany, is, however,

42 Ludewig, Der gelehrte Bauer. Mit D. Christian Gotthold Hoffmanns [...] Vorbericht. Cf. above, $117-18$.

43 Hell, "Observatio transitus Veneris [...] 1761," 49-61.

44 Hell, "Observatio transitus [...] 1761," $36-42$ (quotations on 36 ). 
combined in the two personae of the Cardinal de Luynes, archbishop and honorary member of the Académie des Sciences (Paul d'Albert de Luynes [170388]) and the duke of Chaulnes (Michel Ferdinand d'Albert d'Ailly [1714-69]), who observed the transit from Sens. A full page is spent on the archbishop and duke at the outset of the account of French observations, but in the end no details of their observation are revealed,

for since $[. .$.$] the work that the highly famous friar de Lacaille is prepar-$ ing for publication will include the outstanding observations of the elevated prince of Chaulnes, they could not possibly be referred here by me, utterly inferior to these men with regard to dignity that I am, without incurring the crime of preposterousness. ${ }^{45}$

There follows a long series of observations from France. Most details are taken directly from letters from Lacaille and Lalande, both of whom receive their share of praise from the Viennese court astronomer. Apart from the various observatories in the French capital, however, the Jesuit observatory in Lyon is the only location outside Paris from which Hell presented any datasets.

Following in line after France, Britannia receives its praise as well. At the opening of a four-page account, Britain is singled out as "the parent of the sublimest of intellects, including astronomers." ${ }^{46}$ Summaries of observation sets from Greenwich, London (multiple locations), and Liskeard in Cornwall are included. There is no particular praise of Sweden, except that the importance of observations from this northern territory is evident from the fact that astronomers here had the opportunity to witness both ingress and egress. Three pages spent on three observers-Wargentin, Samuel Klingenstierna (16981765), and Johan Carl Wilcke (1732-96) — at a single site, the Royal Observatory in Stockholm, is still a fairly spacious coverage for a Lutheran territory. ${ }^{47}$ Orthodox Russia is also offered coverage on the same account: the advantageous geographical location of St. Petersburg merited a couple of pages in Hell's report. ${ }^{48}$ The only country outside of the vicinity of the Habsburg lands in which the imperial and confessional factor is again reiterated is Spain. Here, Hell's acquaintance and ally from Vienna, Rieger, is praised. Ample space-threeand-a-half pages - are given to him and other Jesuits in Madrid, in particular Father Weindling (Jan/Juan Wendlingen [1715-90]), originally called from

45 Hell, “Observatio transitus [...] 1761," 37.

46 Hell, "Observatio transitus [...] 1761," 42-45.

47 Hell, "Observatio transitus [...] 1761," 89-92.

48 Hell, "Observatio transitus [...] 1761," 92-94. 
Bohemia by King Ferdinand VI $(1713-59$, r.1746-59) to fill the post as royal astronomer. ${ }^{49}$

If we look more closely at how Hell assembled information for his report, we find that in Russia, a correspondent of Hell's, physicist Joseph Adam Braun (1712-68), provided data from his own private observation as well as those made at the Imperial Observatory in St. Petersburg. Information concerning the various English observations was assembled by the Swedish astronomer Bengt Ferner (later nobled Ferrner [1724-1802]), who was in Paris at the time of the transit. ${ }^{50} \mathrm{He}$ sent extracts from his correspondence with English astronomers to Hell, who in turn included these extracts in the report. Information on the Swedish observations took another detour: the section on observations from Stockholm was based entirely on a letter from Lacaille and an article in the Journal étranger (Foreign journal) of Paris. ${ }^{51}$ As far as the German-, French-, and Italian-speaking regions are concerned, more direct routes of communication were obviously used: Hell communicated directly with most observers, who sent him their elaborate observation data either in manuscript (as did Braun from St. Petersburg) or in the form of printed brochures (as did Zanotti from Bologna).

On the final analysis, the operation of the Jesuit network in 1761 was extremely helpful in underpinning Hell as an astronomer of international reputation, but it was not the only leverage to which he could resort. His connections in the Society's Italian and German assistancies were particularly effective in providing him with a considerable number of observations for his Venus transit report. Elsewhere, his contacts were still developing as of 1761 . His conspicuous status as imperial and royal astronomer probably counted more than his membership in the Society of Jesus when astronomers in places like St. Petersburg and Paris bothered to supply information for his journal. It is the combination of the two roles-Jesuit and court astronomer- that gave Hell a prominent position in the Venus transit project of 1761 .

As mentioned, Hell published a sequel to the report two years later, filling eighteen pages of a longer list entitled "Observationes astronomicae anni 1761 \& 1762: Viennae, et aliis locis factae” (Astronomical observations from the year

49 Hell, “Observatio transitus [...] 1761," 45-49.

5o In the Ephemerides, his name is misspelled as "Fermer." At the latest by May 1761, he was a correspondent of Hell's. Cf. Bengt Ferrner, Resa i Europa: En astronom, industrispion och teaterhabitué genom Danmark, Tyskland, Holland, England, Frankrike och Italien 1758-1760 (Uppsala: Almqvist \& Wiksells, 1956), 388-90.

51 Lacaille's letter has not been found. The article in the Journal étranger, however, titled "Observations du passage de Vénus sur le disque du Soleil, faites à Stockholm, à Gottingue, à Rome \& à Vienne," can be found in the issue of July 1761, 195-214. 
1761 and 1762 , made in Vienna and elsewhere). ${ }^{52}$ In this addition to the Venus transit coverage in the Ephemerides, we find observations from Tranquebar and the Cape of Good Hope along with the observations of the two most famous French expeditionists of 1761 , Pingré on the Isle of Rodrigues (taken from a letter by Messier) and Chappe d'Auteroche in Tobolsk (taken from a printed report as well as a letter "benevolently communicated to me by that author").53 Finally, with the publication of a calculation of the solar parallax based on virtually the entire range of the 1761 Venus transit observations by Anders Planman, an astronomer and professor of physics at the University of Åbo (Turku), the full harvest of the global enterprise eventually found its way to print in Hell's Ephemerides. Grateful users of the annual could hardly have avoided the conclusion that access to all this stock of knowledge was largely thanks to the spider in the web: Hell, in whom the faithful Jesuit, the loyal servant of the Austrian dynasty and government, and the diligent, competent, and useful member of the "republic of astronomy" were inextricably intertwined as building blocks of a carefully constructed public persona.

Lessons Learned

The main interest of contemporary astronomers, as stressed by Zanotti in the quote at the beginning of this chapter, was to calculate the size of the solar parallax. For the attainment of this goal, it was vital to have as many reliable observations from sites ranging as far apart as possible. Logistical and political obstacles aside, it ought to have been a straightforward process. However, not only the weather but also a range of technical and optical challenges complicated the project and made a seamless calculation of the solar parallax impossible. As a broad generalization, there turned out to be at least three sources of error involved in the delicate process of observing a Venus transit.

First, regardless of whether the method of Halley or that of Delisle was chosen, exact time-keeping was a crucial factor. John Harrison (1693-1776) invented the chronometer just on the eve of the transits of Venus. However, only prototypes of the technology were at hand, and these were widely held to be insufficiently tested for scientific use. ${ }^{54}$ Thus, pendulum clocks were the only

$52 \quad$ Hell, Ephemerides 1764 (1763), 208-25.

53 Hell, Ephemerides 1764 (1763), 221.

54 Cf., e.g., Jim Bennett, "The Travels and Trials of Mr Harrison's Timekeeper," in Instruments, Travel, and Science: Itineraries of Precision from the Seventeenth to the Twentieth Century, ed. Marie-Noëlle Bourguet, Christian Licoppe, and H. Otto Sibum (London: Routledge, 2002), 75-95. 
aid available, both in 1761 and in 1769 . Cook did not even take a chronometer on his first circumnavigation of the globe: the moments of ingress and egress were determined by means of standard pendulum clocks. ${ }^{55} \mathrm{~A}$ pendulum clock, however, cannot be transported while it is running and needs to be corrected astronomically over several days in order to be held reliable. Besides, its retardation or acceleration compared to the Sun would vary from day to day, depending on the temperature. For most purposes, George Graham's (1675-1751) temperature-compensated mercury pendulum solved this problem, but a retardation or acceleration of a few seconds every twenty-four hours was still common. For the delicate observations of a transit, where each moment needed to be determined to the exact second, this uncertainty was unacceptable, which is why so many of the Venus transit reports include tables of timekeeping stating the retardation or acceleration of the clock over many days. To pick another example from 1769, Hell used two pendulum clocks in Vardø: one from Vienna, the other from Copenhagen. Both were constructed with temperature-compensated pendulums, so as not to be too severely affected by climatic factors. Nevertheless, they had to be tested against astronomical observations over several weeks leading up to the transit. ${ }^{56}$ The problem regarding clocks was particularly acute in the case of temporary observation sites set up during expeditions. However, as shown by the case of Caspar Müller above, lack of proper time-keeping also rendered the data of some amateur observers questionable.

As a second difficulty, the moments to be observed were particularly the second, third, and fourth contacts of Venus with the Sun's limb. The very first contact, that of Venus's exterior contact at ingress, was generally held to be too difficult to observe. (Venus being invisible on a daytime sky, the observer would simply not know where to look for it until the contact had taken place and the ingress had in fact started. ${ }^{57}$ ) However, during the transit of Venus in 1761 , a

55 See, e.g., Peter Aughton, Endeavour: The Story of Captain Cook's First Great Epic Voyage (Moreton-in-Marsh: Windrush, 1999), 11.

56 Only a small extract of these tests found inclusion in the Venus transit report (Observatio transitus Veneris [...] Wardoehusii, 61-69). Hell's manuscript “Observationes astronomicæ et Cæteræ in itinere litterario Viennā Wardoëhusium usque factæ" (from 1768 to 1769 , preserved at the wUS) contains a longer series of tests, starting April 26 and ending June 4, 1769. Another description containing extracts from these tests is extant in an untitled manuscript of Hell, starting with the words "NB De Horologijs" (1769, wUs).

57 Halley in fact insisted that only the interior contacts were to be used, i.e., the time span between the occurrence of the second and third contacts was the focus of his attention (cf. Halley, "Methodus singularis"). Later astronomers extended their attention to the exterior contacts as well, particularly the fourth and last contact of Venus with the limb of the Sun. 
totally unexpected problem occurred. Instead of entering and leaving the Sun in the form of a well-defined round spot, Venus was seen to take the form of a black drop around the moments of second and third contact. To some observers, this phenomenon seemed to last for almost a whole minute. There may have been several causes of the "black-drop effect": disturbances in the Earth's atmosphere or that of Venus; some diffraction of light in the astronomical tubes of that time; astigmatism in the eye of the observer; or merely the standard blurring of an image when two objects are very close to each other and the light is too dim for the human eye to distinguish between them. In any case, "a combination of solar limb darkening and telescopic point-spread functions" has been a matter of dispute right up to the present time, ${ }^{58}$ and whatever the cause, the phenomenon contributed to making the results of 1761 ambiguous. For the 1769 transit, the astronomical community was better prepared, and several reports include illustrations detailing the optical difficulties involved (see fig. 6). This did not eradicate the ambiguity of the data, but it was helpful when the observations of various observers were compared.

The third problem was that the path of Venus in front of the Sun as seen from widely separated sites turned out to shift far less than anticipated by Halley. There was no way that the difference in latitude between stations could suffice: knowledge of each station's longitude was required as well. In theory, the difference in longitude between two places could be measured simply by transporting a running clock between them. The difference in local time, as revealed by simple observations of the Sun or stars, would then reveal the difference in longitude between the two places. However, as mentioned earlier, this is an impossible procedure when using a pendulum clock. Hence, astronomers on expeditions did their best by adjusting their clocks to local meantime and then used celestial phenomena such as occultations of the moons of Jupiter or eclipses of the moon or the Sun, compared to observations of the same event communicated by other astronomers in faraway places, to compute the longitude: a very delicate and time-consuming process indeed. ${ }^{59}$ For the 1769 transit of Venus, however, a solar eclipse was predicted to take place on the

58 See, e.g., Maor, Venus in Transit, 95-97; Bradley Schaefer Jr., "The Transit of Venus and the Notorious Black Drop Effect," Journal for the History of Astronomy 32, no. 4 (2001): 325-36; J.M. [Jay Myron] Pasachoff, Glenn Schneider, and Leon Golub, "The Black Drop Effect Explained," in Kurtz, Proceedings, 242-53; quotation from J.M. Pasachoff and Naomi Pasachoff, "Helge Kragh, The Moon that Wasn't" (review), Physics in Perspective 12 (2010): 105-8, here 107 .

59 Even at a foremost center of astronomical research like Paris, astronomers spent almost the entire eighteenth century defining the exact position of the observatory. See Moutchnik, Forschung und Lehre, 101. Bearing this in mind, it should come as no surprise that the 


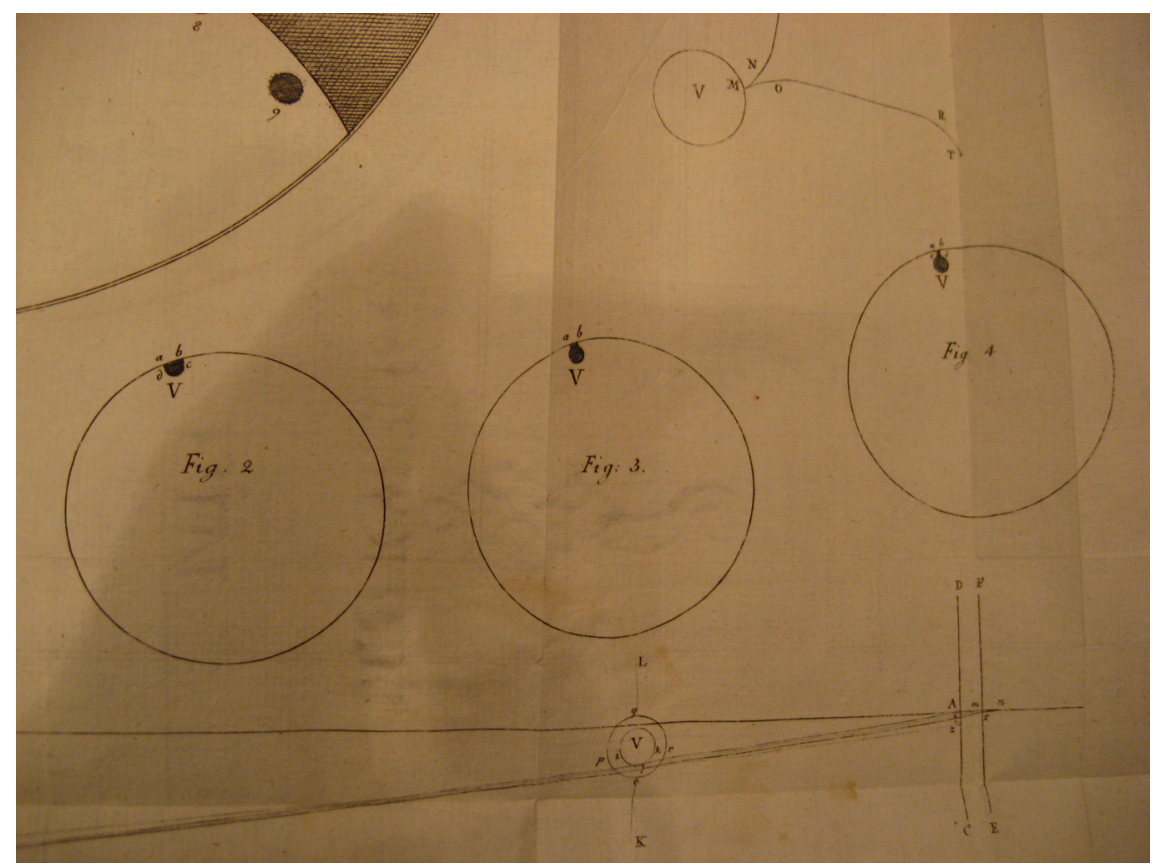

FIGURE 6 The black drop effect as depicted by Daniel Melander

Daniel Melander (later ennobled Melanderhielm [1726-1810]), professor of astronomy at Uppsala, included this illustration in his 1769 report "Uttydning på de Phænomener, hvilka åtfölja Planeten Veneris Passage genom Solen” (Interpretation of the phenomena that follow the transit of the planet Venus through the Sun). Melander's figures 2, 3, and 4 show formations of Venus (V) during interior contact at ingress. Digitized by Per Pippin Aspaas

very day after the event. Most observers therefore used observations of this eclipse as the basis for their longitude determination. Again, however, when observing the eclipse, a similar set of sources of error had to be accounted for: atmospheric disturbances during the eclipse, minute inaccuracies in timekeeping, resulting from sudden changes in temperature, the subjective discernment and skill of the observer, and so on. ${ }^{60}$

meridian for temporary observatories in faraway places was liable to a certain degree of error.

6o "It is true that the method which M. Delisle has substituted [to the one of Halley] presupposes that the difference of the meridian between two observatories is known. Every error committed in the difference of meridians will affect the result that can be deduced from the observations" - the editors acknowledged in the Histoire de l'Académie Royale des Sciences pour l'année 1757 [1762], 85. 
The three main sources of error mentioned above were also the "weapons" with which astronomers challenged each other in the debates ensuing after the 1761 transit. In order to bring all the data into harmony, it was necessary to consider some features of various observations doubtful. The longitude might have been erroneously determined, the clocks wrongly adjusted, or the practical skills of the observer(s) insufficient. Given the ambition, publicity, and the sheer amount of money invested in the project, it may well be that such assessments aroused a certain degree of anger among those whose observations were deemed unreliable. The discussion of the even more complex 1769 Venus transit ventures in Chapter 7 will give occasion to reflect in greater detail on what this enterprise reveals about the nature of eighteenth-century scientific culture, especially the notions and practices of sociability that governed it. For now, it suffices to point out that, judging from the tone of the main papers on the solar parallax published in the aftermath of 1761 , it seems to be an exaggeration to describe this as a "quarrel between French and British astronomers." ${ }^{11}$ Quite the contrary: the astronomers involved were generally careful to use polite language when discussing their colleagues' observations and calculations. This strategy was a prudent one: most astronomical datasets are useless when not compared with other observations. ${ }^{62}$ Cutting off correspondence by giving offense risked a loss of access to precious material for future research, especially as the next transit was approaching within just a few years.

Halley's predictions included ones relating to the expected precision of the calculations to be made. He famously anticipated that his method would result in a calculation of the solar distance with a margin of error of no more than 0.2 percent. ${ }^{63}$ However, given the sources of error listed above, it is small wonder that computations of the solar parallax based on all the 1761 observations

61 For contemporary claims about a "(scientific) quarrel" between British and French astronomers occasioned by the 1761 transit, see Christian Mayer, Ad Augustissimam Russiarum omnium Catharinam II: Alexiewnam Imperatricem expositio de transitu Veneris ante discum Solis d. 23 Maii, 1769 [...] (St. Petersburg: Academia Scientiarum, 1769), preface, [v]; Maximilian Hell, "De parallaxi Solis ex observationibus transitus Veneris anno 1769," Ephemerides 1773 (1772), 1-116, here 113-14.

62 For more on this aspect of early modern astronomy, see, e.g., Sven Widmalm, "A Commerce of Letters: Astronomical Communication in the 18th Century," Science Studies 5 (1992): 43-58; Peter Brosche, "Korrespondierende Beobachtungen," in Wissenschaftskommunikation in Europa im 18. und 19. Jahrhundert: Beiträge der Tagung vom 5. und 6. Dezember 2008 an der Akademie gemeinnütziger Wissenschaften zu Erfurt, ed. Ingrid Kästner (Aachen: Shaker Verlag, 2009), 95-99.

63 Halley, "Methodus singularis," 460. 
varied from 8.28" (Planman), ${ }^{64}$ 8.33" (Stepan Yakovlevich Rumovskii [17341812]), ${ }^{65} 8.615^{\prime \prime}$ (Lambert Heinrich Röhl [1724-90]), ${ }^{66}$ and 8.69" (James Short [1710-68]) (17 $^{67}$ to 9.0o" (Hell, Lalande), ${ }^{68}$ 9.26" (Giovanni Battista Audiffredi [1714-94]), ${ }^{69}$ 9.89" (Thomas Hornsby [1733-1810]), ${ }^{70}$ and 10.24" (Pingré). ${ }^{71}$ Expressed in kilometers, the figures of Planman and Pingré equal 158,884,000 and 128,472,000 kilometers, respectively - twenty percent, a far cry from Halley's prediction of 0.2 , and an unacceptable degree of uncertainty to the contemporary "quantifying spirit."72

Despite the discrepancies between the various attempts to determine the solar parallax, the 1761 transit project was far from being a complete failure. Several features of the phenomenon were investigated, and although some observers missed ingress as well as egress, their observations were still of use for purposes other than the solution of the parallax problem. As Zanotti noted, the transit was useful not only for the definition of the solar parallax: "Also, if we turn to the knowledge of the planet Venus itself, this observation is no doubt to be preferred to any other method that can possibly be attempted in

64 Anders Planman, "A Determination of the Solar Parallax Attempted, by a Peculiar Method, from the Observation of the Last Transit of Venus: By Andrew Planman [...] Together with a Letter from Him to Mr. James Short [...]," PTRSL 58 (1768; published 1769, paper written in 1767): 127 .

65 Stepan Rumovskii, "Investigatio parallaxeos Solis ex observatione transitus Veneris per discum Solis Selenginski habita, collate cum observationibus alibi institutis," Novi commentarii Academiae Scientiarum Imperialis Petropolitanae (hereafter: NcASIP) 11 (1765; published 1767): 487-538, here 510 .

66 Lambert Heinrich Röhl, Merkwürdigkeiten von der Durchgängen der Venus durch die Sonne (Greifswald: Röse, 1768), 110.

67 James Short, "Second Paper concerning the Parallax of the Sun Determined from the Late Observations of the Late Transit of Venus [...]," PTRSL 53 (1763; published 1764): 340.

68 Hell, Ephemerides 1764 (1763), 225; Lalande, Astronomie, 1st ed. (Paris: Desaint \& Saillant, 1764), 8 oo.

69 Audiffredi's mean value of the solar parallax as calculated in De Solis parallaxi ad V. Cl. Grandjean de Fouchy [...] Commentarius (Rome, 1766), was 9.26 seconds, according to Luisa Pigatto, "The 1761 Transit of Venus Dispute between Audiffredi and Pingré," in Kurtz, Proceedings, 74-86, here 83 .

70 Thomas Hornsby, "A Discourse of the Parallax of the Sun [...]," PTRSL 53 (1763; published 1764): 467-95, here 494; Hornsby's calculation of "a parallax of the Sun on the day of the transit" of 9.736 seconds represents a mean horizontal parallax of 9.89 seconds; cf. Andreas Verdun, "Die Bestimmung der Sonnen-Parallaxe aus den Venus-Transits im 18. Jahrhundert," Orion 322 (2004/3): 4-20, here 12.

71 Alexandre Guy Pingré, "Nouvelle recherche sur la determination de la parallaxe du Soleil par le passage de Vénus du 6 Juin 1761," Histoire de l'Académie Royale des Sciences pour l'année 1765 (published 1768): 32.

72 We are indebted to Truls Lynne Hansen (personal communication) for calculating these figures, using the present value of Earth's equator radius (6,378 kilometers). 
order to adjust the nodes of its orbit."73 This was commented upon in Hell's report on the 1761 transit, both by Hell himself and by several other observers.

Another feature of most reports on the 1761 transit was the measurement of the size of Venus as seen on the Sun's disc, which had been a matter of dispute since the 1639 observations. Several observers also noticed a luminous ring around Venus at certain stages of the transit, which-sometimes in conjunction with the black-drop effect-inspired them to engage in speculations concerning a possible atmosphere surrounding Venus. One of those to do so was the Russian polymath natural philosopher, historian, and poet Mikhail Vasil'evich Lomonosov (1711-65), who observed the transit of Venus from his private home in St. Petersburg in 1761. However, his report was only printed in limited numbers as a booklet in Russian and German. It was never included in the official periodical of the St. Petersburg Academy and was poorly distributed, if at all, outside Russia. Hence, it seems to have been largely ignored until the late nineteenth century, when it was republished in conjunction with the Venus transit of $1874 .{ }^{74}$ This late nineteenth-century publication has led Russian historians to hail Lomonosov as the discoverer of the atmosphere of Venus. ${ }^{75}$ However, reflections on a possible atmosphere of Venus can be found in numerous reports from several countries, all published in the immediate aftermath of the transit and - unlike Lomonosov's booklet—distributed far and wide in the Republic of Letters. ${ }^{76}$ Indeed, the possibility of an atmosphere surrounding Venus was mentioned in several of the observations compiled by Hell, who allowed the observers to speak for themselves on this issue, although he concluded early on in his 1761 report that the planet was not at all likely to have an atmosphere. ${ }^{77}$

73 Eustachio Zanotti, De Veneris ac Solis congressu, 1.

74 T.P. Kravets and V.L. Chenakal, eds., M.V. Lomonosov: polnoe sobranie sochinenii, vol. 4, Trudy po fizike, astronomii I priborostroeniiu, 1744-1765 gg, general editor S.I. Vavilov (Moscow: Izdatel'stvo Akademii Nauk, 1955), 353-76; 767-74. See also Vladimir Shiltsev, "Lomonosov's Discovery of Venus Atmosphere in 1761: English Translation of Original Publication with Commentaries," https://arxiv.org/abs/1206.3489 (accessed April 15, 2018).

75 In the more recent literature, this claim is sometimes taken as indisputable; cf., e.g., Maor, Venus in Transit, 88-91; Mikhail Ya. Marov, "Mikhail Lomonosov and the Discovery of the Atmosphere of Venus during the 1761 Transit," in Kurtz, Proceedings, 209-19; Hans Ullmaier, Puncta, particulae et phaenomena, 146. For a vindication of Lomonosov, see Vladimir Shiltsev, "The 1761 Discovery of Venus' Atmosphere: Lomonosov and Others," Journal of Astronomical History and Heritage 17, no. 1 (2014): 85-112.

$7^{6}$ For a list of examples, see Aspaas, "Maximilianus Hell," $202 n 44$.

77 Hell, "Observatio transitus [...] 1761," esp. 21, 26, 92-94. 
One conspicuous element of the transits of Venus, which had already been noted by the two amateur astronomers who observed the transit of 1639, was that the planet's size appeared to be considerably larger in the night sky than it did in front of the Sun during a transit. In fact, observers of the transit reported that Venus appeared to have a diameter of less than one arc minute; most micrometer determinations gave about fifty-eight seconds, or just short of a hundredth part of the Sun's disc. In his 1761 report, Hell explains how, during the nights before and after the transit, Venus appeared in the sky as a bright star of approximately one arc minute and seventeen seconds, ${ }^{78}$ or almost thirty-three percent larger than when viewed against the disc of the Sun. What could be the cause of this sudden diminution? Hell discusses various hypotheses that might explain the phenomenon and concludes that it was most likely to be caused by a certain optic tendency, causing dark objects to appear smaller when viewed against a light background and light objects to appear larger in front of a dark background. This tendency, combined with other optical factors caused by the lenses of the astronomical tubes and the smoked glasses that were used for observations of the Sun, seemed to Hell to be the most likely reason for the change of size of Venus. Further research was needed, however, and his wording in this context is very cautious. ${ }^{79}$ As to the adjustment of the nodes of the planet's orbit, Hell used various observations of the path of Venus across the Sun's disc to determine the coming transits of Venus in the years 1769 and 1874 as seen from the center of the Earth. He also calculated the visibility of the solar eclipse that was to take place on June $4,1769 .{ }^{80}$

A final inference that could be drawn from the transit was that Venus probably had no moon. From time to time, various astronomers had argued its existence, among them the conseiller au Grand Conseil Armand-Henri Baudouin de Guémadeuc (1734/37-1817). In a lecture held at the Académie Royale des Sciences in Paris on May 20, 1761 and printed immediately afterward, Baudouin reported observations made by his friend Jacques Montaigne (1716-85?) in Limoges, who had seen a gleaming object beside Venus on four occasions earlier the same month. Montaigne - and his patron Baudouin — interpreted this as the much-sought moon of Venus. ${ }^{81}$ The most likely appearance of such an

78 Hell, "Observatio transitus [...] 1761," 24-25, 99-100.

79 Hell, "Observatio transitus [...] 1761," 24-28.

8o Hell, "Observatio transitus [...] 1761," $110-15$.

81 The full title was Mémoire sur la découverte du satellite de Venus, \& sur les nouvelles observations qui viennent d'être faites à ce sujet; Lu à l'Academie Royale des Sciences le 20 Mai 1761. On this memoir and its reception, see Kragh, Moon That Wasn't, esp. 44-56. To his references, we may add J.G. [Johann Georg?] Krünitz, "Verzeichniß der vornehmsten Schriften von der Venus und dem Merkur, und dem Durchgange dieser Planeten durch 
object as a moon of Venus would be a minuscule spot somewhere on the disc of the Sun just before, during, or after the transit. In the 1760 preparatory manual, Hell had in fact reminded observers that

finally, both on the day preceding the transit, and on the day of the transit itself, the disc of the Sun should be investigated frequently, to see whether perhaps some smaller, perfectly round spot is there to be seen on the disc of the Sun, a spot moving either in the same or the opposite direction as Venus, but at a speed either exceeding, or at least equalingcertainly not trailing behind - that of Venus. Such a spot, moving in such a way, should represent the moon of Venus, which various observers believe they have seen long ago, under other circumstances. ${ }^{82}$

Many did look for it, but no one reported having seen such a thing. ${ }^{83}$ Hell also remained silent about the possible existence (or non-existence) of this moon in his report of 1761 .

In 1765 , however, a refutation of all "observations" of the moon of Venus as nothing more than optical illusions was issued in Vienna with the title "On the Moon of Venus" (De satellite Veneris). The author of this rather sensational publication was none other than Maximilian Hell. There were two factors that had led him to publish this work, he explained. One was that a few years earlier he had presented his thoughts on the non-existence of the "Venus moon" in a letter to Lacaille, his formal contact at the Académie des Sciences in Paris. After Lacaille's death in 1762 , this letter was transferred to the hands of others, and Hell felt embarrassed that the preliminary thoughts he had intended to ventilate to Lacaille alone were now being discussed by several savants in France. The other stimulus was that, in 1764 , another set of "observations" of the "Venus moon" - this time from Copenhagen—was published, and since

die Sonnenscheibe," Neues Hamburgisches Magazin 6, no. 37 (1769): 114-56, esp. 119, and Marlot, Les passages de Vénus, 101-4. Baudouin's memoir - remarkably, given its date-is referred to by Hell in a letter to Lalande dated Vienna, June 12, 1761. It is also mentioned in his printed report on the transit ("Observatio transitus Veneris [...] 1761," 38). Neither of these references is accompanied by any criticism on Hell's part.

82 Hell, Transitus Veneris, 10.

83 See, e.g., Fer[r]ner, "An Account of the Observations on the Same Transit Made in and near Paris [...]," PTRSL 52, no. 1 (1761; published 1762): 225; or Wargentin's assessment of the results of the Swedish Venus transit observations, "Anmärkningar öfver Planeten Veneris gång genom Solens Discus," KVAH 23 (July-September 1761): 179. For further references, see Kragh, Moon That Wasn't. 
even Baudouin now urged Hell to publish his work, the time was ripe for an elaborate engagement of the subject. ${ }^{84}$

Hell's argumentation was based on experiments whereby he had succeeded in creating optical illusions, where a tiny, illusory bright spot was produced beside a larger, real gleaming object, viewed through a tube in a dark chamber. Most astronomers realized that with this, the case was settled. As one reviewer remarked about Hell's "sagacious remarks and experiments" (scharfsinnigen Bemerkungen und Versuchen): "It is a shame that the moon of Venus has disappeared: some of the jokers here had already decided to call it by the witty name of 'Cupid." 85 In 1768, Hell's treatise was reissued in the Nova acta eruditorum of Leipzig. ${ }^{86}$ Even so, there were observers looking — naturally, to no avail-for traces of this moon during the 1769 transit as well. ${ }^{87}$

84 Maximilian Hell, De satellite Veneris (Vienna: Trattner, 1765), 3-15.

85 Krünitz, "Verzeichniß," 117-18.

86 Nova acta eruditorum (February-March 1768): 49-126.

87 The observers organized by the Russian Academy in 1769 were given specific orders to look for the moon of Venus. Cf. Stepan Rumovskii, Nabliudeniia iavleniia venery v solntse v rossiiskoi imperii $v 1769$ godu uchinennyia s istoricheskim preduvedomleniem (St. Petersburg: Imperatorskaia Akademia Nauk, 1771), 45. Christian Mayer in his report on the Venus transit of 1769 also explains that he has been on the lookout for the moon of Venus but saw no trace of it; see Christian Mayer, "Expositio utriusque observationibus et Veneris et eclipsis Solaris factae Petropoli in specula astronomica," NcASIP 13 (1768; published 1769): 559. In the more elaborate treatise addressed to Catherine II, he denies the existence of this moon, see Mayer, $A d[. .$.$] Catharinam [...] Imperatricem expositio, 285; cf. 140$. Likewise, two Uppsala astronomers looked for the moon of Venus in 1769 but saw no trace of it. Eric Prosperin, "Utdrag af Observationerna på Veneris inträde i Solen, d. 3 Jun. 1769, som blifvit gjorda på observatorium i Upsala," Kongliga Vetenskaps Academiens Handlingar (hereafter: $K V A H$ ) 31 (April-June 1769): 158-59; Fredric Mallet, "Berättelse om det som kunnat observeras uti Pello, vid Veneris gang förbi Solen, den 3 och 4 Junii 1769," KVAH 31 (July-September 1769): 222-23. The British observers also seem to have been instructed to look for the moon of Venus in 1769; cf. Kragh, Moon That Wasn't, 58. Despite the universal failure to see a moon besides Venus on the Sun's disc, the debate arose again in the mid1770 s when an astronomer at the Berlin Academy of Sciences, Johann Heinrich Lambert (1728-77), produced an article criticizing Hell's monograph ("Essai d'une théorie du satellite de Vénus," Nouveaux Mémoires de l'Académie Royale des Sciences et Belles-Lettres [1773; published 1775]: 222-50) and even went as far as announcing, in the Berlin Astronomisches Jahrbuch for the years 1777-78, that the moon of Venus would be visible in front of the Sun on June 1, 1777. Hell refutes this prediction in the Ephemerides 1778 (1777), 7, and in several contributions to the Wienerisches Diarium and the Realzeitung. He also mentions Lambert's prediction unfavorably in some of his letters (see the letters to Fixlmillner, dated Vienna, August 31, 1776, November 27, 1776, and February 15, 1777; published with comments by Rabenalt, "Astronomische Forschung," 119-23). For further sources, see also Kragh, Moon That Wasn't, esp. 80-84. 
The debate on the notorious "moon of Venus" was soon followed by another one in which Hell was involved. As mentioned, Hell added as a sequel to his 1761 memoir some remarks about the visibility of Venus during the coming transits of 1769 and 1874 . One of his conclusions was that the 1769 transit was not going to be visible in Vienna because the Sun would then be below the horizon. This conclusion was not obvious to every contemporary specialist, including the French astronomer Claude-Étienne Trébuchet (1722-84). When in 1764 Trébuchet published a work in which he argued against the conclusions of Hell, this provoked a brief review by the Viennese astronomer in the appendix of his Ephemerides.$^{88}$ Trébuchet, for his part, defended his position in a lengthy letter published in the Journal des Sçavans for October 1766, concurring with the editors of the journal in their praise for the 1765 issue of the Ephemerides, but maintaining his disagreement. A summary of Hell's reply was then published in the Journal des Sçavans in August 1767; Trébuchet's rejoinder to this was also printed separately in 1770 and even personally sent by the author to Hell—though by this time Hell had been proven right, as the 1769 transit of Venus was indeed not visible in Vienna. ${ }^{89}$ However, although the core of the debate was a disagreement about the exact orbit of Venus, it soon also involved the existence (or non-existence) of the "moon of Venus," the feasibility of solar eclipses for longitude determination, the methods of Halley and Delisle for computing the solar parallax, the correct interpretation of a mappemonde of the transit of 1769 that had been published by Lalande, and so on. ${ }^{90}$ Trébuchet's doggedness in the affair may have been fueled by more than purely scientific concerns. Introduced in the "Lettre à Messieurs les auteurs de Journal des Sçavans" (Letter to the gentlemen authors of the Journal des Sçavans ) as an "old servant of the queen" from the town of Auxerre, he was in fact a calculateur employed at the Connoissance des temps by Lalande. ${ }^{91}$ While Connoissance

88 Hell, "Observatio litteraria," in Ephemerides 1765 (1764), 364-68.

89 Trebuchet, "Lettre à Messieurs les auteurs du Journal des Sçavans sur les passages du Vénus, \& sur l'eclipse de Soleil arrivée en 1764," JS (October 1766): 644-57; Hell, "Extrait d'une lettre du R.P. Hell [...] sur le passage de Vénus observé en 1761," JS (August 1767): 624-26; Trebuchet, Lettre à Messieurs les auteurs du Journal des Sçavans sur le passage de Vénus [separate reprint, with additions] (Bouillon: Société Typographique, 1770). The second Lettre of Trebuchet was-according to a handwritten message in the hand of Trebuchet on the back page of Hell's copy (wUs), dated Auxerre, September 16, 1770-written in 1768 and published in a Recueil philosophique. Only a brief resumé appeared in the Journal des Sçavans, as late as February 1771, 118-19.

$90 \quad$ Trebuchet, "Lettre à Messieurs les auteurs"; Hell, "Extrait d'une lettre." See also Alexandre Guy Pingré, "Mémoire sur la parallaxe du Soleil, déduite des meilleurs observations de la durée du passage de Vénus sur son disque le 3 juin 1769," HARS (1775): 398-420.

91 Guy Boistel, "Nicole-Reine Lepaute et l'Hortensia," Cahiers Clairaut 108 (2004): 13-17. 
des temps was Europe's astronomical almanac of the most illustrious pedigree, by the late 1760 s the Ephemerides was emerging as a dynamic rival, and as we shall see, by the aftermath of the 1769 transit - when the original stakes of the controversy were undermined but Trébuchet still kept up the fight- the personal animosity between Lalande and Hell was out in the public domain. There is no evidence to corroborate the assumption that Lalande was sending Trébuchet into the field, but the possibility remains open.

\section{“Quonam autem fructu?": Taking Stock}

We now move beyond the 1761 transit of Venus as such, to take another look at Hell's reputation as it developed during the course of the 1760 . Trébuchet's gesture toward Hell's stature even while engaging in a controversy with him leads us to the question of the returns on the investment into the fashioning of Hell's observatory and Vienna as a node of astronomical knowledge. From the map of contemporary European astronomy as reflected in the pages of the Ephemerides, we turn to the question of the place of Hell, the Imperial and Royal Observatory of Vienna, and the Ephemerides itself on that map. Were one to judge merely by local responses, the imperial and royal astronomer was already "world famous in his home" by 1762 , when the Wienerisches Diariuman official gazette, no doubt prioritizing information reflecting positively on the Habsburg monarchy—-reviewed Hell's memoir of the transit of Venus and simply referred to him as "our renowned astronomer," adding that "whoever is familiar with his works, is convinced well in advance that deep insight, reliability, order, and precision will be found in the present one." The author of the review hastened to express his agreement with Hell's view, advanced in the introduction, that the contemplation of the condition of astronomy in a state allows one to assess accurately the general progress of the sciences therenaturally implying that in Austria the situation was reassuring. ${ }^{92}$ The journal followed Hell's activities in astronomy and other fields quite closely and reported on them from time to time, even before the sensational invitation from

$92 W D$, no. 54 (July 7,1762 ): appendix, 9. It must be added that if, in our engagement with Hell's report above, the "national" element was played down in order to enable a more nuanced assessment of the confessional element in the 1761 Venus transit enterprise, the review's tone is unabashedly "Austrian." The very first astronomer mentioned by name after Hell is "our Rieger" in Madrid, closely followed by "another famous Austrian astronomer" whose "rare efforts and services" should cause the reader delight—none other than the amateur Ehrmann zum Schlug. Right next to the report on Hell's "Observatio," the paper brings an account on Weiss's Trnava observation reports. 
Copenhagen. These included announcements, and then a review of the booklet on magnets in $1762 ;{ }^{93}$ a report on attempts made by Hell and others at healing patients suffering from toothache by magnetism in $1766 ;{ }^{94}$ exchanges between Hell and Weiss about a comet Weiss observed in 1766, and about meteorological measurements in $1767 .{ }^{95}$ The journal and the authorities behind it clearly regarded it important to keep the public abreast of developments in the observatory and the activities of its director.

To be sure, Hell's own judgment of his own stature dovetailed nicely with the opinion of the journalist about his "renown." The manner of address and tone of the treatise on the moon of Venus is worth recalling here. An initial name-dropping is undoubtedly intended to locate the author in the august company of colleagues such as the "famous" (Wargentin and the French "comet hunter," Messier) and the "brilliant" (the geophysicist and astronomer Jean-Jacques Dortous de Mairan [1678-1771]), some of them identified as his "intimate friends" (Lacaille) or simply as "our father" (Joseph Louis Lagrange [Giuseppe Luigi Lagrangia (1736-1813)] —actually sixteen years Hell's junior, but already recognized as one of the greatest mathematicians of the age; "father" here refers to his status as a Jesuit), with all of whom he maintains a mutually inspiring correspondence and who have proved themselves to be a captive audience for his corrections of their research results. ${ }^{96}$ This might well create an aura of presumptuousness, were it not for the tone of elegant, subtle irony in Hell's addressing the celebrities who are his putative interlocutors: a tone not of upstart self-assertion, but one of dignified self-confidence on the part of a scholar who is firmly aware of his status on the map of contemporary learning.

For a final apparently self-congratulatory assessment, one might turn to the balance struck by Hell about the impact of the Ephemerides in the preface to its twentieth volume (1776). While this was published several years after the purview of the present chapter, the achievements Hell boasted about there were more or less in hand by the late $1760 \mathrm{~s}$ :

The present, 1776 year of these Ephemerides, is the twentieth in an uninterrupted series published since 1757 for the use of the public by the Imperial and Royal Observatory of the University of Vienna. But what are

$W D$, no. 75 (September 18, 1762): 7 ; no. 79 (October 2, 1762): 9-10.

$94 W D$, no. 26 (March 29, 1766): 10-12. Cf. the discussion on Hell's engagement with Franz Anton Mesmer below in Chapter 7, 357-61.

$95 W D$, no. 31 (April 16, 1766): 9-11; no. 4 (January 14, 1767): 7-8; no. 6 (January 21, 1767): 7-8.

$9^{6}$ Hell, De satellite Veneris, 13. 
the fruits [quonam autem fructu]? This whoever wishes to know, may understand from reading the famous periodicals of France, the Journal des Sçavans, Journal étranger, or Ephem. Astronomicae Parisinae [i.e., the Connoissance des temps], as well as of Germany, the Göttingische Anzeigen, and other astronomical books. ${ }^{97}$

Hell's satisfaction was not unfounded. From 1758, the Journal des Sçavans reported on the appearance and the contents of the Ephemerides each year, ${ }^{98}$ at varying length, but usually in substantial detail. As hinted above, the awakening of French interest in the Ephemerides may be ascribed to the operation of the "Jesuit network," with two of Hell's German Jesuit contacts, Mayer and Huberti, bringing the first volume to the attention of Parisian astronomers on the occasion of a visit in 1757 at the observatories of the French capital. ${ }^{99}$ In any case, given that the number of astronomical works reported and reviewed in this most widely circulated French review journal was a maximum of about half a dozen every year, the coverage it secured for the Ephemerides is quite noteworthy. From the point of view of publicity, polemical engagement with Hell's positions in the Journal des Sçavans, as in the case of Trébuchet, was also far from being obviously of adverse effect: ${ }^{100}$ being regularly reported in the Journal des Sçavans, engaging responses from reputed figures of the French academic public, the Ephemerides and Hell earned as much notice among that public as was possible. A private, but very important response by Lalande-by this time, the most renowned French astronomer of his age, himself a highly prolific science writer and editor of the Connoissance, the French counterpart of the Ephemerides - in a letter to Weiss couched the French astronomer's admiration for Hell in a comparison of his own significant textbook, the Astronomie (1764), with the famous Almagestum novum (New almagest [1651]) of Giovanni Battista Riccioli (1598-1671):

97 Hell, Ephemerides 1776 (1775), 2 (Monitum). To the titles mentioned, Hell could have added the Leipzig-based Nova acta eruditorum as well, which also published reviews of the Ephemerides from 1762 on.

98 See, e.g., the review of the Ephemerides for the year 1761 in the JS (October 1761): 672-75. This volume was sent by Hell to the editors of the journal with an explicit request for a review (letter from Hell to the editors of the journal, dated March 18, 1761; wUS). Shortly afterward, a review of the Ephemerides for 1762 appeared in the Nova acta eruditorum (February 1762): 49-58.

99 Huberti to Hell, October 3, 1757. wus, Manuscripte Hell, vol. 3.

100 Another case was, more significantly, the critical letters of Lalande himself in February 1773 concerning the parallax calculations of both Hell and Lexell from the 1769 Venus transit, to be discussed below. JS (February 1773): 90-93, 113-15. 
I would have liked to follow in the footsteps of Riccioli and produce a work of the same length as his, but I would never have found a publisher to cover the costs of its printing. It is difficult for us in Paris to publish books on mathematical subjects; an author could hardly expect to receive a copy or two from the typographer in return for a voluminous manuscript: I admire how our friend father Hell, however famous and erudite, is able to publish a quite lengthy volume of his Ephemerides every single year. ${ }^{101}$

As the role of the Göttingische Anzeigen von gelehrten Sachen (Göttingen reports on learned matters), in which the Ephemerides was also mentioned at generous frequency, was similar on the German scene to the Journal des $S c ̧ a-$ vans on the French one, the same assumption of wide recognition probably holds for Germany, too. The Ephemerides was first reported in the Göttingische Anzeigen in 1764-possibly thanks to the extensive 1761 Venus transit coverage - and was specifically commended on account of the lasting value of the materials published in it besides the astronomical tables for the year. ${ }^{102}$ Thereafter, the "excellent annual" (vortreffliche Jahrbuch), in which the material is "very conveniently arranged" (sehr bequem eingerichtet), ${ }^{103}$ was reviewed regularly (although not each year). The special attention given to the appendices demonstrates that its distinctiveness did not escape the attention of the reviewer, the Göttingen mathematician, professor of geometrics and physics (and enlightened polymath), Abraham Gotthelf Kästner. ${ }^{104}$ Kästner would later express his grave concern in commenting on the 1776 volume that as Hell's efforts to replace the leverage of the Society of Jesus through the foundation of a scientific society (academy) by the monarch became thwarted, the Ephemerides - which in regard of the "accuracy of its calculations, its richness of detail, and its serviceableness has been superior to all others" - might be discontinued. ${ }^{105}$ One might also add that today copies of the Ephemerides (for the most part, of the entire series) are available in at least fifteen academic libraries in Germany - another indicator of wide dissemination.

\footnotetext{
101 Lalande to Weiss in Trnava, dated Paris, June 10, 1764, in Vargha, Correspondence de Ferenc Weiss, 1:57. As noted and will be developed, Lalande's attitude to Hell was soon to change.

102 Göttingische Anzeigen von gelehrten Sachen (hereafter: GAgS) [12]:2, no. 98 (August 16, 1764): 788-90.

103 GAgS [20]:2, no. 134 (November 7, 1772): 1138; [17]:2, no. 97 (August 14, 1769): 879 .

104 On the highly complex character and diverse activities of Kästner, see Rainer Baasner, Abraham Gotthelf Kästner, Aufklärer (1719-180o) (Tübingen: Niemeyer, 1991).

105 GAgS, [25]:1 no. 3 (January 6, 1777): 24.
} 
As for the avenues of this dissemination, once again we possess little conclusive evidence. Whatever documents on the trade of the imperial printing house Trattner, which was also the publisher of the Ephemerides, still exist, we have been unable to access them. Hell's correspondence is a testimony that he was himself highly active in the circulation of the annual: in several of his letters, we find the clause "herewith I am sending a copy of my latest Ephemerides [...]." ${ }^{106}$ Hell was a well-organized and systematic man. We may safely assume that each of his correspondents regularly received their personal copies. Some of them, like Kästner, were not content just using the Ephemerides in their work but faithfully reported on each volume at important venues, thus contributing substantially to the journal's circulation and growing reputation.

In contrast to the impressive coverage of the achievements of the Ephemerides in the French and the German scientific public sphere, there is virtually no trace of any awareness of it in Britain. Given the character of the Nautical Almanac, it is little surprise that it makes no reference at all to the Viennese annual (nor does it pay attention to any astronomical work done anywhere else than Greenwich). However, the Philosophical Transactions of the Royal Society published texts by astronomers or accounts of their work on a regular basis, including a great many non-British figures with whom Hell maintained contact, but scarcely to Hell himself. ${ }^{107}$ In view of the fact that the work of Nevil Maskelyne and other English astronomers is quite extensively reported and used in the Ephemerides, and that the 1769 transit of Venus was a central concern for both journals, this lack of reciprocity is a puzzle and needs further attention. ${ }^{108}$ However, even if British lack of interest was real, Hell was successful

106 In a letter of March 18, 1761, Hell explicitly asked the editors of the Journal des Sçavans to review the Ephemerides (wus). See further Hell to Franz Weiss, January 11, 1783 (Pinzger, Hell emlékezete, 2:137); Hell to Abraham Gotthelf Kästner, March 6, 1785; Hell to Kästner, January 26, 1788 (Niedersächsische Staats- und Universitätsbibliothek in Göttingen, hereafter: NSUвG. See Hungarian translation in György Gábor Csaba, ed., A csillagász Hell Miksa írásaiból [Budapest: Magyar Csillagászati Egyesület, 1997], 58).

107 The only exception we found is a passing reference to the Ephemerides of 1765 and Hell's calculation of the longitude of Vienna by the Swedish astronomer Pehr Wilhelm Wargentin. "A Letter from Mr. Wargentin, F.R.S. and Secretary at the Royal Academy of Sciences at Stockholm, to the Rev. Mr. Maskelyne, M.A. F.R.S. and Royal Astronomer at Greenwich Containing an Essay of a New Method of Determining the Longitude of Places, from Observations of the Eclipses of Jupiter's Satellites," PTRSL (1766): 280, 284.

108 Yet, as Maskelyne's account books for $1773-85$ demonstrate, throughout 1776 and 1777 he had astronomical equipment manufactured by London instrument-makers upon orders by Count Károly Eszterházy, bishop of Eger, for the new observatory there. Hell was the chief advisor of the building of this observatory (for details, see below). Copies of Maskelyne's accounts (held at the archive of the Royal Greenwich Observatory, RGO 35/134) are 
in carving out an international presence for the Ephemerides just by consolidating its status in the French and the German academic scene.

"What astronomer does not know of the excellent Ephemerides of Vienna?," the astronomer royal of Berlin, Johann (Jean) III Bernoulli, exclaimed in the first issue of his remarkable compendium for astronomers in $1771 .{ }^{109}$ Bernoulli had a strong point. Closely associated with the almanac that he almost singlehandedly raised among the top-ranking ones in the field (and in certain respects, superior to all others), Hell had become a leading international personality in contemporary astronomy as the transit of 1769 approached. No doubt, this was made possible in good measure by the unity of purpose that existed between a reform-minded government that was (still) sufficiently well disposed to the Society of Jesus to lend patronage to its endeavors in modern learning, and Hell as an eminent Jesuit man of science. Not only was he widely known as an accurate calculator and an assiduous compiler of others' observations but also as one-illustrated by his writings on the theory of Venus-who discussed with authority several of the central themes of theoretical astronomy, and contested the theories of others with stamina and convincing force. He was recognized as an able observer as well as an important networker, helping colleagues in the provinces to obtain high-quality instruments, coordinating the activities of both professional and amateur observers, and exchanging data with astronomical centers abroad. It was certainly not out of peripheral obscurity that he emerged as one of the emblematic figures in the 1769 Venus transit observations. He was almost destined to do so.

in Vargha priv. Cf. also Ottó Kelényi B., Az egri érseki líceum csillagvizsgálójának története (Budapest: Athenaeum, 1930), 6.

109 Johann (Jean) III Bernoulli, Recueil pour les astronomes (Berlin: Chez l'Auteur, 1771-73), 1:154. 